
(http://creativecommons.org/licenses/by/4.0/), which permits unrestricted re-use, distribution, and reproduction in any medium, provided the original work is properly cited.

doi:10.1017/mdh.2020.18

\title{
Medical Bacteriology and Medical Genetics, 1880-1940: A Call for Synthesis
}

\author{
AMIR TEICHER * \\ Department of History, Tel Aviv University, Tel Aviv 6997801, Israel
}

\begin{abstract}
Between 1880 and 1920 the medical quest to unearth the causes of disease saw two pathbreaking discoveries. One was the bacteriological revolution - the identification of specific germs as causal agents of specific diseases (anthrax, tuberculosis, diphtheria, cholera and so on), and the simultaneous effort to develop disinfection techniques and immunisation measures to combat these diseases. The other was the rediscovery of Mendel's laws of heredity and the resulting emergence of medical genetics, where an entire set of medical maladies (deafness, blindness, bodily deformities, haemophilia, Huntington's chorea, feeble-mindedness and many mental diseases) were identified - rightly or wrongly - as genetically determined. The 'germ theory of disease' and the 'gene theory of disease' shared striking, all-too-often overlooked similarities. Both theories built on shared epistemological assumptions that influenced their explanatory mechanisms and their overall conceptual frameworks; both mobilised similar visual and linguistic vocabulary; both appropriated - and enforced - prevailing cultural and gender norms; and both enshrined broadly parallel hygienic practices. Reflecting similar social concerns, medical bacteriology and medical genetics acquired kindred scientific and societal configurations, which this paper highlights and scrutinises.
\end{abstract}

Keywords: Bacteriology, Eugenics, Genes, Genetics, Germs, Hygiene

\section{Introduction}

Between 1880 and 1920 the medical quest to unearth the causes of disease saw two pathbreaking transformations. One was the bacteriological revolution: the identification of specific germs as causal agents of specific diseases - anthrax, tuberculosis, diphtheria, cholera and other epidemics of the period - and the simultaneous effort to develop disinfection techniques and immunisation measures to combat those diseases. The other was the rediscovery of Mendel's laws of heredity and the subsequent identification of

* Email address for correspondence: teichera@tauex.tau.ac.il

Research for this paper was supported by the Israeli Science Foundation (grant no. 145/18). I thank Luc Berlivet, Francesco Cassata, Greg Radick, Michael Dietrich, Marsha Richmond, Charles Pence, Ehud Lamm, Snait Gissis and Volker Roelcke, as well as two anonymous reviewers, for their helpful comments on earlier versions of this paper. I thank Clara Hestermann and Lea Herzig for their assistance and Sarah Mandel for her language editing. 
an entire set of medical maladies - deafness, blindness, bodily deformities, haemophilia, Huntington's chorea, feeble-mindedness and many mental diseases - as genetically determined.

In most of the historical literature, these two transformations are examined separately. ${ }^{1}$ Germs and infectious diseases, on the one hand, and genes and hereditary diseases, on the other, are usually analysed by different scholars and treated as essentially separate categories, each related to a different set of characteristics, aetiologies, treatment practices and preventative measures. This paper takes the opposite approach: it underscores the core commonalities of medical bacteriology and medical genetics as theories of disease causation, traces striking similarities between their conceptual frameworks, social assumptions and cultural characterisations, and reveals the affinities between the pragmatic steps devised for coping with devious germs and with malignant genes in the public medical domain. ${ }^{2}$

Before commencing our analysis, it is essential to remedy a common historical misconception regarding the development of medical genetics. As a scientific field, medical genetics is often portrayed as a subset (and, by implication, later outgrowth), of human genetics, itself seen as a special case of the study of genetics in general. ${ }^{3}$ Such a view is anachronistic. The first indications for Mendelian inheritance in man were of metabolic and physiological defects (Alkaptonuria and Brachydactyly). ${ }^{4}$ Studies conducted throughout the first decade of the twentieth century followed the same trajectory, focusing on pathological heredity and making only occasional forays into the inheritance of regular traits, such as eye colour. In 1909, with accumulating supporting evidence on his side, the champion of Mendelism in Britain, William Bateson, made it clear that 'Of Mendelian inheritance of normal characteristics in man there is yet but little evidence'. ${ }^{5}$ In its application to man, genetics was therefore 'medical' from the very beginning and only subsequently was it extended to include non-pathological traits. The subset preceded the set; it was, in fact, its forerunner. ${ }^{6}$

A similar dynamic also prevailed before the rise of Mendelism. As Carlos LópezBeltrán has observed, already in the eighteenth and nineteenth centuries the overall

\footnotetext{
${ }^{1}$ Notable exceptions to this rule will be addressed below.

2 Technically speaking, the term 'medical genetics' was coined in the $1930 \mathrm{~s}$, and became a recognised clinical practice only in the 1950s and 1960s, with the rise of cytogenetics and biochemistry. See Charles J. Epstein, 'Medical Genetics in the Genomic Medicine of the 21st Century', American Journal of Human Genetics, 79, 3 (2006), 434-8. The use of the term 'medical genetics' (resp. 'medical bacteriology') throughout this paper is therefore descriptive, not historical, and is designed to distinguish the application of genetic (resp. bacteriological) theories to address medical issues from its use in other contexts, such as plant and animal breeding (resp. fermentation).

${ }^{3}$ Exceptional in this regard is Nathaniel Comfort, The Science of Human Perfection (New Haven, CT: Yale University Press, 2012), and see below.

4 Archibald E. Garrod, 'The Incidence of Alkaptonuria: A Study in Chemical Individuality', Lancet, 160, 4137 (1902), 1616-20; William Curtis Farabee, Hereditary and Sexual Influence in Meristic Variation: A Study of Digital Malformations in Man (PhD thesis: Harvard University, 1903).

${ }^{5}$ William Bateson, Mendel's Principles of Heredity (Cambridge: Cambridge University Press, 1909), 205. Eye colour and hair type were notable exceptions, but even these traits were often pathologised through their association with foreign races. See in this respect the pedagogical chart in https://collections.ushmm.org/search/ catalog/irn5594.

${ }^{6}$ There were intrinsic reasons for that, acknowledged already by contemporaries: inherited pathologies were more easily discerned in human pedigrees than normal variations; and, unlike normal, complex traits, some of them indeed resulted from single-gene mutations, which followed Mendelian regularities more neatly. See Erwin Baur, Eugen Fischer and Fritz Lenz, Menschliche Erblichkeitslehre und Rassenhygiene. 3rd edn (Munich: J. F. Lehmanns, 1927), 177.
} 
study of heredity 'started out as human heredity, in particular, as human pathological heredity'. López-Beltrán stressed the pivotal role that medical practitioners, including psychiatrists and social reformers, had in developing the very concept of biological heredity. It was 'European physicians [who] felt the need, long before other naturalists, to focus on genealogical patterns of trait transmission'. ${ }^{7}$ In their synthetic study of the Cultural History of Heredity, Staffan Müller-Wille and Hans-Jörg Rheinberger also noted that it was not general notions on the permanence of familial character, or 'like-begetslike', that engendered a systematic, scientific exploration of the patterns or process of hereditary transmission; it was on the basis of observations regarding familial diseases, physical peculiarities and other deviations from health that the modern concept of human inheritance developed. ${ }^{8}$

Infamously, early twentieth-century eugenicists drew on the accumulated findings regarding the inheritance of physiological defects and enthusiastically applied genetic models to account for the great menaces of the period - mainly feeble-mindedness and nervous and mental disorders. The resulting research programmes and legislative steps are commonly regarded today as a cruel societal crime, built upon dogmatic, over-simplistic, pseudo-scientific assumptions, with few positive results and many hideous ones. Medical genetics' hagiography has been conveniently cleansed of this widespread application of Mendelian genetics to mental illnesses, the latter having been relegated to the field of socially biased eugenics. ${ }^{9}$ One of the results of this retrospective separation of eugenics and human genetics is the aforementioned popular misrepresentation of the course of the development of genetics itself. From the vantage point of the 1910s and 1920s, the study of mental aberrations such as feeble-mindedness and schizophrenia was as pivotal to the study of genetics - and to the appeal of Mendelism in general - as work on tuberculosis and cholera was to bacteriology two decades earlier. A description of the growth of medical genetics must therefore reincorporate the study of mental disorders, a point stressed most recently in Theodore Porter's book, Genetics in the Madhouse. ${ }^{10}$

As soon as mental diseases are brought back into the story, essential similarities between bacteriology and public-hygiene, and genetics and racial-hygiene, begin to surface. Thus, beyond their shared scientific points of departure - both genetics and bacteriology had roots in botany and cell theory, both were embroiled in questions on species formation and evolution, and both engaged with issues of specificity, polymorphisms and mutability - the application of the two fields to the human domain was inherently entangled with the examination of pathologies. It was anthrax, wound infections and tuberculosis that transformed cells into germs; and it was mostly medical and mental pathologies that showed that human traits conformed to the rules of Mendelian heredity. This common

\footnotetext{
${ }^{7}$ Carlos López-Beltrán, 'The medical origins of heredity', in Staffan Müller-Wille and Hans-Jörg Rheinberger (eds), Heredity Produced: At the Crossroads of Biology, Politics, and Culture, 1500-1870 (Cambridge, MA: The MIT Press, 2007), 105-32 (here 107-9).

${ }^{8}$ Staffan Müller-Wille and Hans-Jörg Rheinberger, A Cultural History of Heredity (Chicago, IL and London: The University of Chicago Press, 2012), 43-4, 58.

${ }^{9}$ For example, of the forty-seven 'Classic Papers on the History of Genetics' reprinted in Peter S. Harper, Landmarks in Medical Genetics (New York, NY: Oxford University Press, 2004), not a single one addresses mental illnesses. The closing reprint, to be sure, is the 1939 'Geneticists' Manifesto', which makes clear that genetic science is a stranger to (Nazi) eugenics and racism. The shadow of eugenics also informs much of the scholarly preoccupation with the dangers of 'geneticization'. For a critique of this latter concept and of its utility, see Michael Arribas-Ayllon, 'After Geneticization', Social Science \& Medicine, 159 (2016), 132-9.

10 Theodore M. Porter, Genetics in the Madhouse (Princeton, NJ: Princeton University Press, 2018).
} 
medical context, as I will show below, superimposed certain conceptual, social and cultural gridlines onto both emerging fields.

Several scholars have already noted some of the similarities I analyse below. In particular, the concept of carrier, which became central to both bacteriology and genetics, raised the need to juxtapose the two fields. John Andrew Mendelsohn commented in 1996 that 'Genetics and the new bacteriology even shared [this] key concept. From the healthy carrier of dangerous germs to the healthy carrier of dangerous or "inferior" germplasm (heterozygous for a recessive gene) appears to have been a relatively short step, though the story of how the term "carrier" became standard in genetics and eugenics remains untold'. ${ }^{11}$ Diane B. Paul offered a more thorough analysis of this issue in her 'Genes and Contagious Disease: The Rise and Fall of a Metaphor'. ${ }^{12}$ Sociologist of medicine, Peter Conrad also teased out several parallels between late twentieth-century genetic discourse and earlier bacteriological explanations. Inspired by Rene Dubos' Mirage of Health, Conrad observed that late 1990s genetic discourse, like bacteriology at the time, tended towards specific aetiology, the disregard of environmental factors and a mechanistic view of bodily functions. He argued that 'the public depiction of the new genetics aligns perfectly with the old germ theory model and, independent of scientific validity, fuels the acceptance of genetics in medicine and society'. ${ }^{13}$ More recently, Nathaniel Comfort directly tackled the relations between the fields as part of his study of the history of medical genetics, and described the rise, during the 1930s, of what he called 'a germ theory of genes'. As Comfort observed, 'Through the analogy with public health, genes are like germs, unitary agents of disease. The mental hospital becomes the sanatorium. Sterilization is the equivalent of quarantine'. ${ }^{14}$

Comfort drew these comparisons from three American pioneers of medical genetics (William Allan, Madge Thurlow Macklin and Laurence Snyder) who used the language of bacteriology to discuss genetics during the 1930s. One can find similar analogies made by American, British and German scholars even earlier. ${ }^{15}$ Indeed, as Paul has pointed out, already ' $[\mathrm{b}] \mathrm{y}$ the $1920 \mathrm{~s}$, discussions of bad heredity were often framed in the

\footnotetext{
11 John Andrew Mendelsohn, 'Cultures of Bacteriology: Formation and Transformation of a Science in France and Germany, 1870-1914' (unpublished PhD thesis: Princeton University, 1996), 781. Mendelsohn's remark is still valid. In future publications I intend to explore more fully the historical context of the rise of the carrier concept and its social ramifications; below I will point out some of its prominent medical features.

12 Diane B. Paul, 'Genes and contagious disease: the rise and fall of a metaphor', in The Politics of Heredity: Essays on Eugenics, Biomedicine, and the Nature-Nurture Debate (New York: State University of New York Press, 1998), Ch. 9.

13 Peter Conrad, 'A Mirage of Genes', Sociology of Health and Illness, 21, 2 (1999), 228-41 (quote from 231); Rene Dubos, Mirage of Health (New York, NY: Harper and Row, 1959).

14 Nathaniel Comfort, "Polyhybrid Heterogeneous Bastards": Promoting Medical Genetics in America in the 1930s and 1940s', Journal of the History of Medicine and Allied Sciences, 61, 6 (2006), 415-55 (here 433-7, 454); Comfort, Human Perfection, op. cit. (note 3), 90-2. Another significant work that deals with the relations between bacteriology and genetics is Jean-Paul Gaudillière and Ilana Löwy (eds), Heredity and Infection: The History of Disease Transmission (London: Routledge, 2001). This work gathers a series of case studies showing that for many late nineteenth- and early twentieth-century medical scholars, it was obvious that a combination of hereditary and environmental factors, coupled with bacterial exposure, worked together to make a body healthy, resistant or ill, and that the categories of infection and heredity thus overlapped. The present analysis, however, focuses not on the areas where the lines between bacteriology and genetics were blurred, but, on the contrary, on their common features precisely in the domains where they were perceived as independent and distinct explanatory schemes.

${ }^{15}$ For example, Edwin G. Conklin, Heredity and Environment in the Development of Men (Princeton, NJ: Princeton University Press, 1923), 307; Herbert S. Jennings, The Biological Basis of Human Nature (New York, NY: W. W. Norton, 1930), 234.
} 
language of infectious disease' ${ }^{16}$ As we will see below, however, the use of bacteriological terminology by geneticists was not merely 'metaphorical', in the sense that genes were compared to, or equated with, germs. A systematic treatment of the similarities between the two fields will reveal that their commonalities ran deeper than merely discursive uses (as Paul, Conrad and Comfort imply) and began earlier than previously assumed. In many respects, the discussion on genes and germs was scientifically and culturally construed using similar principles, so that making analogies between the two fields became almost inevitable. Using examples from Germany, Britain and the US, each section in this paper will explore similarities between elements of bacteriology and genetics from 1880 to the 1940 s, beginning with their explanatory structures, moving on to their related representational conventions and vocabulary, and continuing to the social practices they enshrined and the cultural anxieties, racial stereotypes and gender norms they evoked. ${ }^{17}$ To conclude I will reflect on the wider historical context underlying the similarities analysed.

\section{Principal Similarities in the Historical Developments of Medical Bacteriology and Medical Genetics}

Seen somewhat schematically, the development of both medical bacteriology and medical genetics may be described as follows. (1) The agent responsible for a certain pathological state is declared to have been identified. (2) Motivated to search for similar causative explanations for parallel medical conditions, researchers identify similar disease agents, a fact which contributes to the overall appeal of the new reductionist approach to the study of an entire class of medical phenomena. (3) Despite these initial successes, the ensuing research efforts soon encounter a backlash, as bio-medical realities (the diseases themselves), and those who encounter them daily (physicians, clinicians and the sick), refuse to conform to one-sided explanations offered by some of the champions of the new theory. (4) Gradually, a more complex explanation emerges. At this stage, both bacteriology and genetics embrace notions regarding the actual power of the pathogenic agent to exert its influence (virulence in the former case; penetrance in the latter) and of the variability in the expression of the agent among different human beings (constitution/disposition, seed vs. soil; expressivity, norm of reaction). ${ }^{18}$ These concepts

\footnotetext{
16 Paul, op. cit. (note 12), 160.

${ }^{17}$ French medicine will require a separate analysis. Here it should suffice to note that both its style of bacteriology (or, microbiology) and its hereditarian theories differed from those popular in Germany and the US. The differences between Koch's and Pasteur's approaches are quite well known; see, e.g. Mendelsohn, op. cit. (note 11). When it comes to genetics, while in Germany and the US Mendelism provided the key to studying human inherited defects, in France, the reverse was true: Mendelian theory was considered as potentially applicable to normal inheritance, but only marginally relevant for studying the complexities of pathological heredity. Relatedly, and in a way which clearly corresponds to the Pastorian approach to disease, French eugenics was more 'environmental' than its Anglo-Saxon counterparts, and focused on pregnancy and maternal well-being, not on genetic selection. See William H. Schneider, Quality and Quantity (Cambridge: Cambridge University Press, 1990); Jean-Paul Gaudillière, 'Mendelism and Medicine: Controlling Human Inheritance in Local Contexts, 1920-60', Comptes Rendus de l'Académie des Sciences - Series III - Sciences de la Vie, 323, 12 (2000), 1117-26; Jean-Paul Gaudillière and Ilana Löwy, 'The hereditary transmission of human pathologies between 1900 and 1940: the good reasons not to become "Mendelian"', in Staffan Müller-Wille and Christina Brandt (eds), Heredity Explored: Between Public Domain and Experimental Science, 1850-1930 (Cambridge, MA: MIT Press, 2016), 311-36.

18 Originally, both virulence and penetrance were primarily operational concepts: if a person carrying disease agents failed to display the expected symptoms, those agents were a posteriori defined as 'avirulent' or only 'partially penetrant'. On virulence, see J. Andrew Mendelsohn, "Like All That Lives": Biology, Medicine and Bacteria in the Age of Pasteur and Koch', History and Philosophy of the Life Sciences, 24, 1 (2002), 3-36.
} 
replace antithetic distinctions that earlier generations of doctors often applied to differentiate the sources of disease, such as proximate/remote-, primary/secondary- or predisposing/exciting-causes. ${ }^{19}$

In the refashioned medical view, adopted by physicians first with regard to epidemic diseases and later with respect to inherited pathologies, the disease agents (pathogens/ pathological genes) take the role of irritants, stimulants or 'potentials'. The actual impact of these necessary yet insufficient pathogens depends on individual factors, which are themselves influenced by various external parameters, such as nutrition, alcohol consumption or exposure to stress. Whether a particular medical practitioner gives precedence to the role of the former (the germs/genes) or to the significance of the latter (individual susceptibility, social factors) often corresponds to that practitioner's professional position. Bedside clinicians are naturally more inclined to favour explanations that allow for therapeutic intervention and that maximise the gravity of individual behaviour or diet in the causation of diseases; public health officials and eugenicists, oriented towards the prophylaxis of the national, not individual, body, are more inclined towards explanations that magnify the role of the pathogens in causing disease and of the state in combating it. ${ }^{20}$

For both groups, however, these novel conceptualisations have fundamental theoretical implications. Between 1890 and 1920, in light of the insights stemming from bacteriology, a new understanding of what constituted health and disease crystallised and became institutionalised in the work of public health bureaus. It included several essential components. (1) Whereas the old (Galenic) view defined health as equilibrium, and disease as a body out-of-balance, the proponents of medical bacteriology defined health as the condition of a body that was pure and uncontaminated, or unpenetrated, by external disease agents. $^{21}$ (2) Contamination itself did not originate from vaguely defined, ever-present miasma or filth; a dense vapour, polluted water or contaminated milk were harmful only as long as they functioned as routes through which specific germs travelled. (3) These germs, not the environment, were the ultimate reason for disease; individual infected bodies that spread them became the ultimate source of infection, and it was the task of health authorities to detect these individuals and block the existing routes of germ transmission. ${ }^{22}$

Between 1910 and 1940, an equivalent view took hold with regard to inherited maladies. (1) A hereditarily healthy body was defined as a pure one, yet the meaning of such purity changed. The popular idea of disharmonious racial crossing - the hereditarian equivalent of the humoral unbalanced body - gradually gave way to genetic theory, which

On penetrance, see Manfred D. Laubichler and Sahorta Sarkar, 'Flies, genes and brains: Oskar Vogt, Nicolai Timoféeff-Ressovsky, and the origin of the concepts of penetrance and expressivity', in Lisa S. Parker and Rachel A. Ankeny (eds), Mutating Concepts, Evolving Disciplines: Genetics, Medicine, and Society (Dordrecht: Kluwer, 2002), 63-86.

${ }^{19}$ For the significance of these distinctions in nineteenth-century medical thinking, see Christopher Hamlin, 'Predisposing Causes and Public Health in Early Nineteenth-Century Medical Thought', Social History of Medicine, 5, 1 (1992), 43-70.

${ }^{20}$ See the differentiation between hygienists' and clinicians' attitudes towards Pasteur's discoveries in Bruno Latour, The Pasteurization of France (Cambridge, MA: Harvard University Press, 1988); for physicians' motivations to stress the role of heredity, see John C. Waller, "The Illusion of an Explanation": The Concept of Hereditary Disease, 1770-1870', Journal of the History of Medicine and Allied Sciences, 57, 4 (2002), 410-48.

${ }^{21}$ See Linda L. Nash, Inescapable Ecologies: A History of Environment, Disease and Knowledge (Berkeley, CA: University of California Press, 2006), 88-90.

22 See e.g. Hibbert Winslow Hill, The New Public Health (Minneapolis, MN: Press of the Journal-Lancet, 1913), 40 , and further discussion below. 
insisted that a diseased body was simply a body infected by particulate pathogenic genes. ${ }^{23}$ (2) Genetic contamination itself did not originate from vaguely defined, ever-present 'hereditary taints', 'degeneration' or accumulative inherited pathologies; a schizophrenic grandmother or alcoholic grandfather were harmful only if they indeed passed the specific pathological gene to their descendants. ${ }^{24}$ (3) These genes were the ultimate reason for disease; the individual bodies that transferred them were the ultimate source of infection, and it was the task of eugenicists to trace these individuals and block the still viable routes of gene transmission.

The classification of diseases in both medical bacteriology and medical genetics was also refashioned to align with these new (mono-) causal aetiologies. In the new nosology, causes, not symptoms, took centre stage, while the clinical descriptions of disease entities became of secondary importance. For example, three diseases which were, from the clinical point of view, utterly distinct - bubonic plague, septicaemic plague and pneumonic plague - collapsed into three varieties of a single Bacterium pestis (later Pasteurella pestis, and finally Yersinia pestis). ${ }^{25}$ Diseases were not only merged but also separated: 'The differential diagnosis between true and false diphtheria', for instance, 'can be made by bacteriological examination', an official 1895 American report explained. ${ }^{26}$ Christoph Gradmann summarised these transformations: 'Every time a pathogen was identified, the disease in question was newly defined ... the bacteriological laboratory ... could lead to completely novel definitions of a disease. ${ }^{27}$

An almost identical development occurred within genetics, finding its most salient expression in the study of mental disturbances. Until around 1914, Mendelian analysis of mental deviations seemed to accord neatly with Emil Kraepelin's paradigmatic classification of mental diseases into manic-depressive (bi-polar) and schizophrenic (dementia praecox) disorders. ${ }^{28}$ Subsequently, and facing some obvious limitations of their earlier models, German psychiatrists began to reorganise the classification of mental

${ }^{23}$ William B. Provine, 'Geneticists and the Biology of Race Crossing', Science, 182, 4114 (1973), 7906; William H. Tucker, “Inharmoniously adapted to each other": science and racial crosses', in Andrew S. Winston (ed.), Defining Difference: Race and Racism in the History of Psychology (Washington, DC: American Psychological Association, 2004), 109-133.

24 Amir Teicher, 'Caution: Overload. The Troubled Past of Genetic Load', Genetics, 210, 3 (2018), 747-55. Emblematic of this change was the transformation in the meaning of the expression 'hereditarily burdened' in German psychiatry. Whereas at the beginning of the century it was applied to describe anyone with mentally deficient relatives, by the mid-1930s psychiatrists insisted on the need to limit its use to those who actually carried pathological genes. See Hans Luxenburger, 'Der Begriff der Belastung in der Eheberatungstätigkeit des Arztes', Der Erbarzt, 1 (1935), 12-15.

25 See Andrew Cunningham, 'Transforming plague: the laboratory and the identity of infectious disease', in Andrew Cunningham and Perry Williams (eds), The Laboratory Revolution in Medicine (Cambridge: Cambridge University Press, 1992), 209-44.

${ }^{26}$ Hermann M. Biggs, William H. Park and Alfred L. Beebe, 'Report on Bacteriological Investigation and Diagnosis of Diphtheria from May 4, 1893 to May 4, 1894', Scientific Bulletin No. 1, Bacteriological Laboratory, Health Department, City of New York (New York, NY: Martin B. Brown, 1895), 5.

${ }^{27}$ Christoph Gradmann, Laboratory Disease: Robert Koch's Medical Bacteriology (Baltimore, MD: The Johns Hopkins University Press, 2009), 60. See also Mervyn Susser, Causal Thinking in the Health Sciences: Concepts and Strategies of Epidemiology (New York, NY: Oxford University Press, 1973), 23.

${ }^{28}$ Emil Kraepelin, Psychiatrie: Ein Lehrbuch für Studierende und Aerzte (Leipzig: Johann Ambrosius Barth, 1899). Initially, this correspondence between assumed inherited factors and clinical categories facilitated the application of Mendelian notions to the sphere of mental illnesses, a project whose main proponent in Germany was one of Kraepelin's students, Ernst Rüdin. See Anne Cottebrune, 'Zwischen Theorie und Deutung der Vererbung psychischer Störungen: Zur Übertragung des Mendelismus auf die Psychiatrie in Deutschland und in den USA, 1911-30', NTM Zeitschrift für Geschichte der Wissenschaften, Technik und Medizin, 17 (2009), 35-54 (here 36-7). 
illnesses along genetic lines. The category of 'mixed psychosis', used to describe the combination of symptoms from the manic-depressive and the dementia-praecox spectra, was dismantled: mixed psychoses were now seen as nothing more than the chance mixture of genes responsible for the two diseases in a single person - a clinical curiosity perhaps, but a genetic triviality. ${ }^{29}$ For similar reasons, 'Propfschizophrenia' - a state where mental retardation and schizophrenia were both present - was dissolved as a clinical entity, proven to be simply an occurrence, in the same person, of both (inherited) states. ${ }^{30}$ Epilepsy, in turn, was divided into new sub-categories, each inherited independently - and so forth. ${ }^{31}$ In short, psychiatric categories were reordered to comply with assumed genetic components and their observed hereditary patterns. ${ }^{32}$

There were therefore crucial similarities between bacteriology and genetics both in the development of theories of disease causation and in their principles of classification. When it came to individual diagnosis, however, there was an undeniable difference between the two fields. In the case of bacteriology, an actual bacterium was found, stained, photographed, cultured and injected into new animals. At the end of the explanatory road was a laboratory worker armed with a microscope, and it was he (or she) who not only redefined the nature of the disease but also served as the ultimate arbiter for its diagnosis. The laboratory, as the site where clinical suspicions could be affirmed or refuted, thereby became 'the scientific foundation of the public health campaign in America', to use the words of Charles-Edward Amory Winslow, a leading US public health authority. ${ }^{33}$ In medical genetics there was no equivalent of the laboratory verification for the presence and identity of a given gene. As a result, the dual function of the laboratory in bacteriology - proving in principle that the causes of a disease lay in bacteria, and then diagnosing such bacteria in particular cases - was not emulated in medical genetics, where clinical considerations together with genealogical investigations remained indispensable for individual diagnosis. The impalpability of genes differentiated them from germs, which from the very beginning were more tangible and less hypothetical. Let us now turn to how these genes and germs were conceived - and represented.

\section{Representing the Invisible}

One of the essential features common to germs and genes was their invisibility. Discussing 'The Gospel of Germs', Nancy Tomes observed that the fears raised by invisible bacteria were on a continuum with prevalent religious anxieties and popular conceptions of the supernatural worlds. 'By virtue of their religious heritage, ordinary Americans had been conditioned to believe in an "invisible world" dominated by unseen forces that held the

\footnotetext{
${ }^{29}$ Robert Gaupp and Friedrich Mauz, 'Krankheitseinheit und Mischpsychosen', Zeitschrift für die gesamte Neurologie und Psychiatrie, 101, 1 (1926), 1-44.

${ }^{30}$ Carl Brugger, 'Die erbbiologische Stellung der Pfropfschizophrenie', Zeitschrift für die gesamte Neurologie und Psychiatrie, 113 (1927), 348-78.

${ }^{31}$ K. Gerum, 'Beitrag Zur Frage der Erbbiologie der Genuinen Epilepsie, der Epileptoiden Erkrankungen und der Epileptoiden Psychopathie', Zeitschrift für die gesamte Neurologie und Psychiatrie, 115 (1928), 320-422; Hans Roemer, 'Über psychiatrische Erblichkeitsforschung', Archiv für Rassen- und Gesellschaftsbiologie, 9, 3 (1912), 292-329.

${ }^{32}$ For more on this topic, see Porter, op. cit. (note 10), 211-18, 237; Amir Teicher, Social Mendelism: Genetics and the Politics of Race in Germany, 1900-1948 (Cambridge: Cambridge University Press, 2020), Ch. 2.

${ }^{33}$ Charles-Edward Amory Winslow, The Evolution and Significance of the Modern Public Health Campaign (New Haven, CT: Yale University Press, 1935), 36.
} 
power of life and death ... there were striking similarities between traditional fears of malign spirits and the new views of the germs.' ${ }^{34}$ The same religious heritage was also available to those contemplating genes. In a speech given in 1927, American geneticist Herbert Spencer Jennings declared that 'A defective gene - such a thing as produces diabetes, cretinism, feeble-mindedness - is a frightful thing; it is the embodiment, the material realization of a demon of evil; a living self-perpetuating creature, invisible, impalpable, that blasts the human being in bud or in leaf. ${ }^{, 35}$

Notwithstanding the significance of such religious heritage, the realisation that small micro-organisms had immense powers did not necessitate the world of spirits for legitimisation. On the contrary, it was modern science that gave credibility to these ideas. The might of the small particles was grounded in cell theory, which insisted that things as tiny as bacteria and as minuscule as chromosomes had crucial effects on the development of an organism, controlling and regulating life processes and in certain cases leading, in largely still inexplicable ways, to disease, decay and death. ${ }^{36}$ One American mother confessed in 1901: 'I do not believe in telling a child ghost stories to frighten him when he is naughty. When Clifford is naughty I explain the germ theory to him and have him look through a microscope at bacteria. It frightens him terribly, and at the same time inculcates scientific knowledge. ${ }^{37}$ She was not the only one to mobilise existential anxieties to advance scientific education. In its opening pages, the 1913 American Primer of Hygiene, Being a Simple Textbook on Personal Health and How to Keep It compared germs to poisonous plants spreading deadly gasses that kill everyone living nearby. 'We can see a street car coming and get out of its way, but germs we must learn to escape without seeing them. ${ }^{38}$

While germs and genes could not be seen with the naked eye, they could be made visible. This was done through two principal channels. Firstly, from the early days of bacteriology, microphotography and staining techniques exposed and disseminated to scientists and the public alike images of bacteria. This would prove crucial for the persuasiveness of the new microbiological theory. ${ }^{39}$ Two decades later the same techniques also made it possible to see where genes resided - on tiny, worm-like rods, which were themselves very much

\footnotetext{
${ }^{34}$ Nancy Tomes, The Gospel of Germs: Men, Women, and the Microbe in American Life (Cambridge, MA: Harvard University Press, 1998), 7.

${ }^{35}$ Herbert S. Jennings, 'Public Health Progress and Race Progress - Are They Incompatible?', Science, 66, 1698 (1927), 45-50 (here 47-8). British, American and German eugenicists routinely mobilised religious metaphors to describe their tasks and goals. See Christine Rosen, Preaching Eugenics: Religious Leaders and the American Eugenics Movement (New York, NY: Oxford University Press, 2004); Gerald V. O’Brien and Autumn Molinari, 'Religious metaphors as a justification for eugenic control: a historical analysis', in Darla Schumm and Michael Stoltzfus (eds), Disability in Judaism, Christianity, and Islam (New York, NY: Palgrave Macmillan, 2011), 14166.

${ }^{36}$ Pivotal in this regard was Rudolf Virchow, Cellular Pathology, as Based Upon Physiological and Pathological Histology (London: John Churchill, 1860). For another example, see Herbert William Conn, 'Some Uses of Bacteria', Science, 19, 483 (1892), 258-63.

${ }^{37}$ Quoted from 'The Modern Mother'. Detroit Journal via New York Times (9 January 1901), 8, in James Barlament, 'Healthy Fear: Bacteria and Culture in America at the Turn of the Twentieth Century' (unpublished MA thesis: Athens, University of Georgia, 2005), 16.

38 John W. Ritchie and Joseph S. Caldwell, Primer of Hygiene: Being a Simple Textbook on Personal Health and How to Keep It (Yonkers-on-Hudson, NY: World Book Company, 1913), 1-2, 142.

39 Thomas Schlich, "WWichtiger als der Gegenstand selbst”: Die Bedeutung des fotografischen Bildes in der Begründung der bakteriologischen Krankheitsauffassung durch Robert Koch', in Martin Dinges and Thomas Schlich, Neue Wege in der Seuchengeschichte (Stuttgart: Franz Steiner,1995), 143-74.
} 
akin to microbiological pathogens. ${ }^{40}$ While the invisibility of genes and germs was of a very different order, their visual representations in popular books - dependent, as they were, both on morphological bacterial structures as well as on the available photographic and microscopic technologies of the time - erased many of these differences. In many of these representations, the circular shape of microscopical photography coincided with the custom to present germ cells in rounded forms, with the result that bacterial and chromosomal depictions became highly alike (Figures 1,2$).{ }^{41}$

At the same time, genes and germs also became noticeable, albeit indirectly, through their patterns of manifestation in the population. Epidemiologists used the marking of maps with dots, squares or circles not merely to document cases of disease outbreak, but also to track down the source of an epidemic and underscore its modes of transmission and proliferation. Several such maps became well known, such as John Snow's Broad Street Pump map, which predated the bacteriological revolution but was later appropriated by it and iconised as its forerunner, and Robert Koch's maps of cholera in Hamburg; similar maps decorated the professional and popular bacteriological publications of the period (Figure 3). ${ }^{42}$

The parallel in medical genetics were pedigrees of pathologies. Here, the fluid transmitting the disease agents was not polluted water, milk or secretion, but polluted germ-plasm, or blood (Figure 4). By systematically omitting all the healthy ancestors of sick individuals, the overwhelming majority of these pedigrees - printed in eugenic exhibitions, textbooks and scientific papers - presented a single couple, or person, from whom genetic diseases emanated. ${ }^{43}$ Despite their different format, the guiding principle and underlying purpose of both epidemiological maps and pedigree charts was very similar: to identify a singular source of disease which needed to be neutralised to prevent further contamination. Epidemiological maps dealt with transmission in space, pedigrees with transmission through time; but both representation formats reinforced the notion that the reason for illness lay in transmittable agents that could potentially be isolated, implicitly legitimising the efforts of state and medical authorities to prevent further proliferation of germinal contamination by sterilising remaining disease sources.

As noted above, despite the premise, shared by eugenicists and public hygienists alike, that the source of infection lay in humans, those concerned with public health knew all too well that additional factors were at work beyond the disease agent, and that these factors could bring about infection or stem it. In descriptions of the resulting interaction between

\footnotetext{
${ }^{40}$ While visualisation of genes played no role in Mendel's original study, chromosomes became associated with his work soon after it was rediscovered and, for many, proved its validity. Thus, the rise of modern genetics, like the rise of bacteriology, had its interrelated visual armoury, as any textbook of heredity from the time demonstrates.

${ }^{41}$ When cells were represented as parts of tissues, their shape was usually quadrangular. In the context of genetics, however, sex-cells (gametes) were diagrammed alone, and took a circular shape. The same applied to bacteria. For more examples, see Carl Fraenkel and Richard Pfeiffer, Mikrophotographischer Atlas der Bakterienkunde (Berlin: Verlag von August Hirschwald, 1889) and John Buchanan, An Encyclopedia of the Practice of Medicine (New York, NY: R. R. Russell, 1890), 390-425.

42 See Biggs, Park and Beebe, op. cit. (note 26) , 50: 'It has been the practice of the Department during the last year to plat upon a city map the location and date of every case of diphtheria in which the diagnosis had been settled by bacteriological examination.' For additional examples, see Tom Koch, Disease Maps: Epidemics on the Ground (Chicago, IL: The University of Chicago Press, 2011), Ch. 11.

${ }^{43}$ For more examples, see the pedigrees printed in Bateson, op. cit. (note 5), Ch. 12, and in Baur, Fischer, and Lenz, op. cit. (note 6).
} 


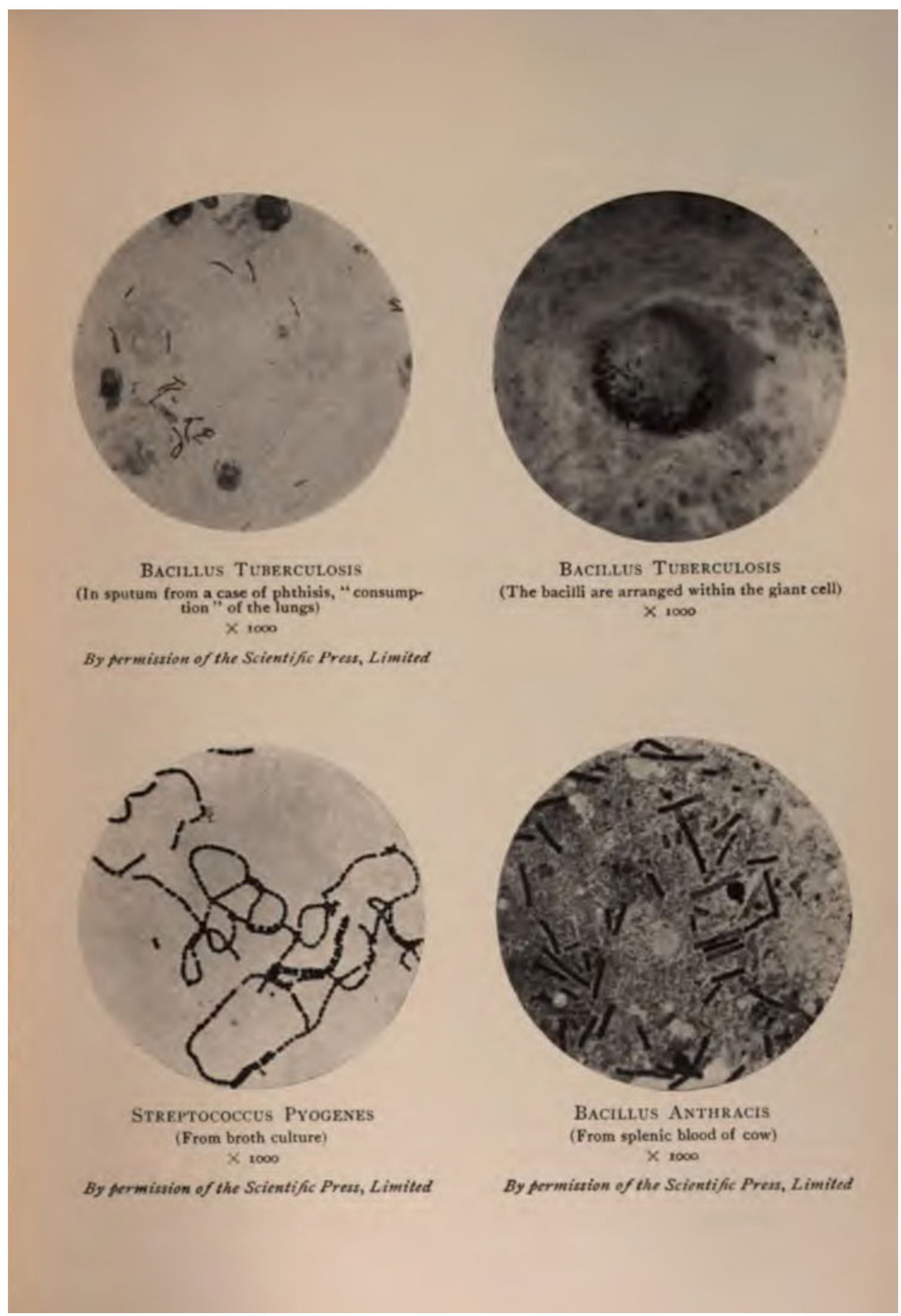

Figure 1: Bacteria. Source: George Newman, Bacteria (New York, NY: G. P. Putnam's Sons, 1899), 280. 


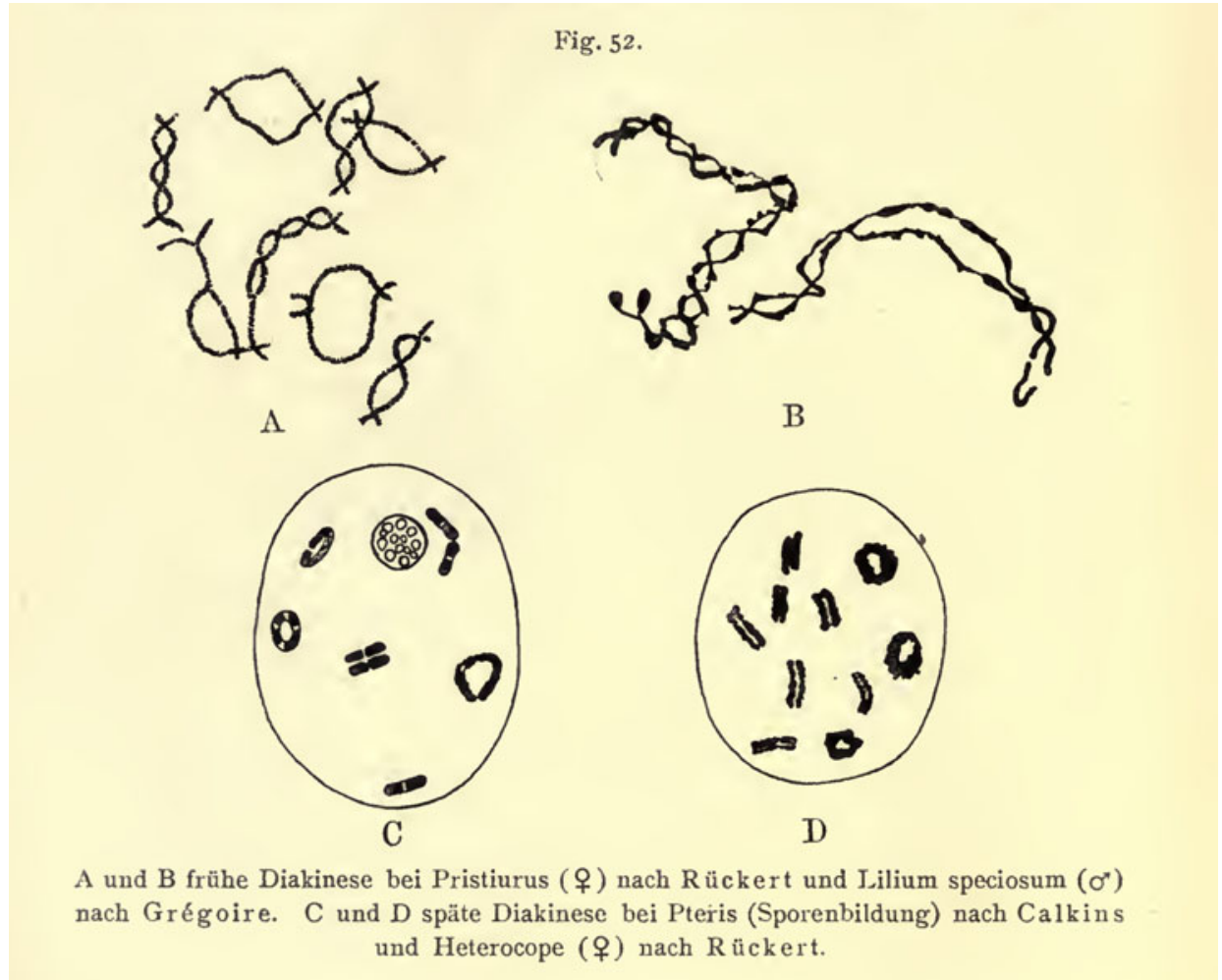

Figure 2: Chromosomes. Source: Valentin Haecker, Allgemeine Vererbungslehre (Braunschweig: Friedr. Vieweg \& Sohn, 1911), 90.

germs and humans, military metaphors were conspicuously common. ${ }^{44}$ 'The organism is a strong place, the microbe is its assailant, and the struggle between them is the infectious disease', explained an 1895 paper published in the American Popular Science Monthly. 'If a person is in general good health, he will offer a vigorous resistance to the microbes. If, on the other hand, his health is not perfect, there will be a point where the defences are weak, and his danger will be proportionately great. ${ }^{45}$ An influential 1909 guide on Civics and Health, which became recommended reading for high-school students, went even further, explaining that

germs migrate for the same reason as man, - search for food, love of conquest, and love of adventure. ... Human sociology imprisons, puts to death, deprives of opportunity to do evil, or reforms those who murder, steal, or slander. Germ sociology teaches us to do the same with injurious germs. We imprison them, we take away their food supply, we kill them outright, or we starve them slowly ... Of utmost consequence is it that the

\footnotetext{
44 This theme has already been analysed extensively in the literature; see in particular Christoph Gradmann, 'Invisible Enemies: Bacteriology and the Language of Politics in Imperial Germany', Science in Context, 13, 1 (2000), 9-30; Silvia Berger, Bakterien in Krieg und Frieden. Eine Geschichte der medizinischen Bakteriologie in Deutschland 1890-1933 (Göttingen: Wallstein, 2009); Marianne Hänseler, Metaphern unter dem Mikroskop. Die epistemische Rolle von Metaphorik in den Wissenschaften und in Robert Kochs Bakteriologie (Zurich: Chronos, 2009).

${ }^{45}$ M. Louis Capitan, 'Microbes as Factors in the Society', Popular Science Monthly, 47, May (1895), 103-9 (quote from 106).
} 


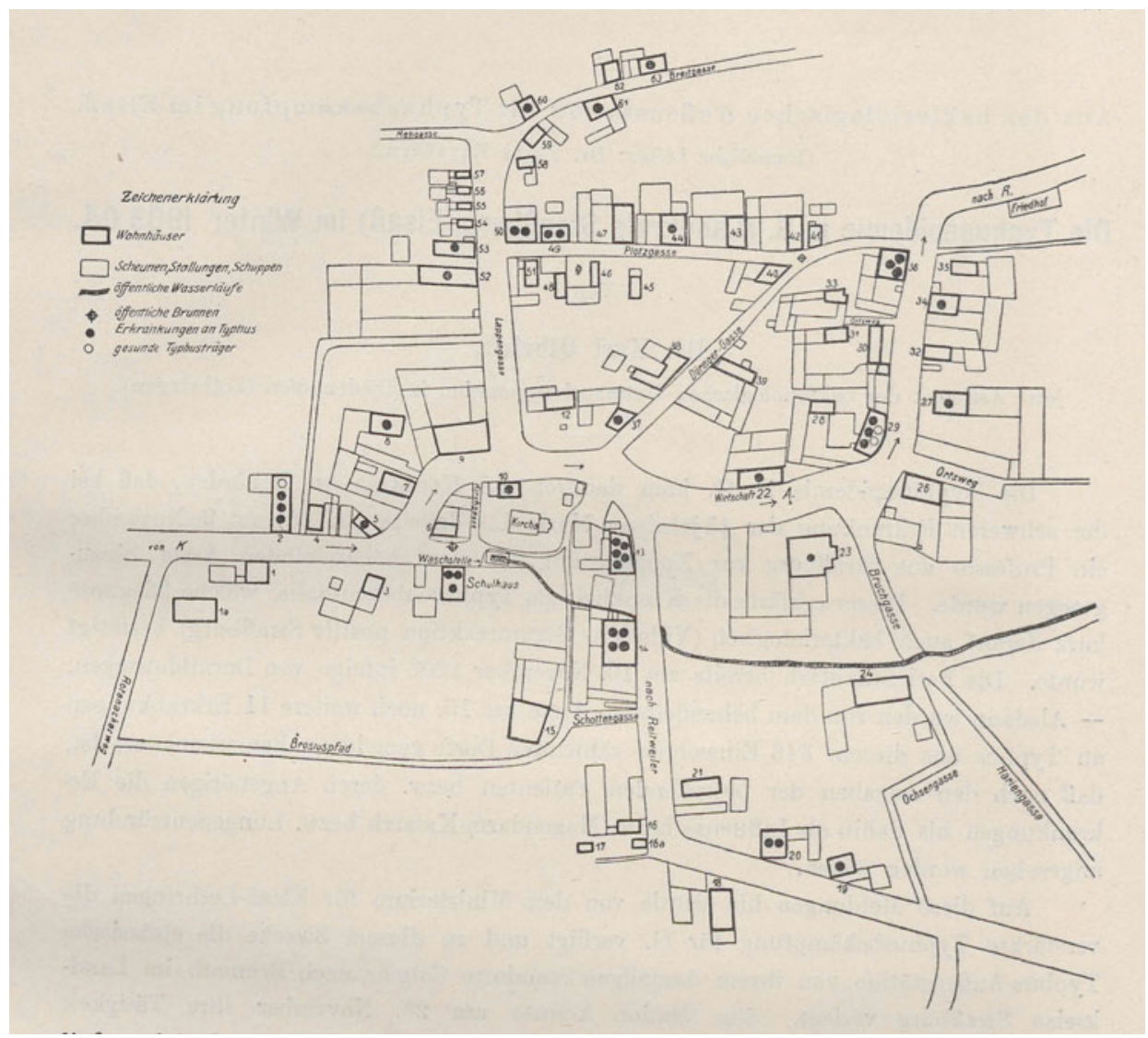

Figure 3: Spatial spread of a bacterial disease. An empty circle signifies a healthy carrier of typhus bacteria; a shaded circle signifies a sick individual. Source: Karl Olbrich, Die Typhusepidemie in G. (Landkreis Straßburg, Erlaß) im Winter 1903/4, in Beiträge zur Bekämpfung des Typhus im Deutschen Reiche (Arbeiten aus dem Kaiserlichen Gesundheitsamte, 24. Band) (Berlin: Julius Springer, 1906), 159-72 (picture from 160).

body's germ consumer - its Pretorian guard - be always armed with vitality ready to vanquish every intruding hostile germ. If we are false to our guard, it will turn traitor and join invaders in attacking us. ${ }^{46}$

Genes, like germs, could be just as dangerous. Yet unlike germs, genes were not natural candidates for portrayal as foreign assailants: after all, genes did not come from outside the human body, they could neither be extracted nor cultivated independent of their 'host', and they were generally perceived as integral to one's being. ${ }^{47}$ Nevertheless,

46 William H. Allen, Civics and Health (Boston, MA: Ginn and Company, 1909), 58-9. The book was recommended by Maurice A. Bigelow, Teachers' Manual of Biology: A Handbook to Accompany the "Applied Biology" and the "Introduction to Biology" by Maurice A. Bigelow and Anna N. Bigelow (New York, NY: Macmillan, 1912), 91, 93, 101; it was also adopted as a textbook in certain American societies; see the book notice in [Eds], 'Civics and Health', Journal of the American Medical Association, 56, 8 (1911), 613-14.

47 Thus, as Owsei Temkin once remarked, although both bacteriology and genetics encouraged an ontological (as opposed to physiological) disease aetiology, the latter engendered 'an "internal" ontological orientation in contrast to the external [orientation] of the bacteriologist'. Owsei Temkin, 'The Scientific Approach to Disease: Specific Entity and Individual Sickness' in The Double Face of Janus and Other Essays in the History of Medicine (Baltimore, MD and London: The Johns Hopkins University Press, 1977), 441-55 (quote from 450). 


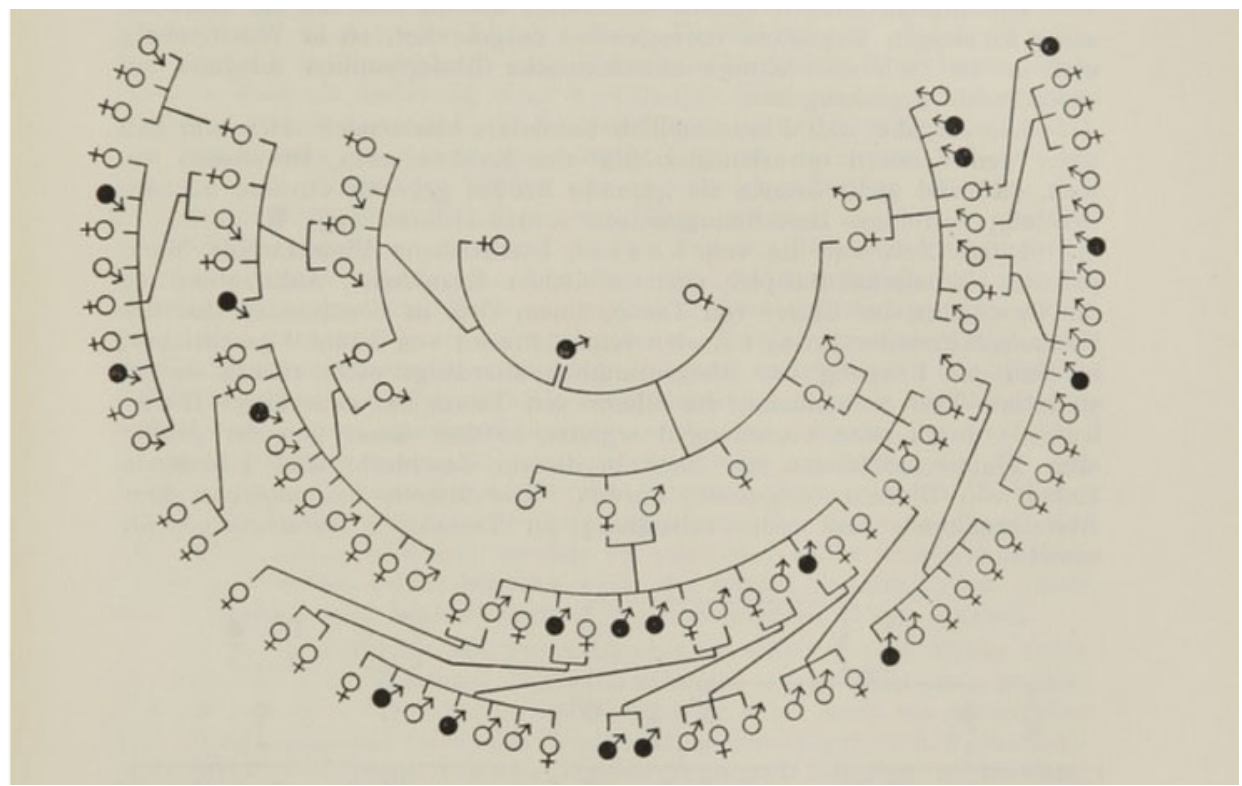

Figure 4: Genealogical spread of a genetic disease (haemophilia). An empty circle signifies a healthy person who might also be a carrier of haemophilia genes; a shaded circle signifies a sick individual. Source: Erwin Baur, Eugen Fischer, and Fritz Lenz, Menschliche Erblichkeitslehre und Rassenhygiene. III ed. (München: J. F. Lehmanns, 1927), 283.

three genetic concepts made it possible to consider even one's own (malignant) genes as alien to one's body. First, the notion of genetic mutations implied that a particular hereditary factor was new, unnatural, incompatible with the needs of an organism and potentially strange and harmful. ${ }^{48}$ Second, the concept of recessivity (and most mutant genes were also recessive) meant that a distressing gap existed between one's traits and one's genes, and that genes could hide within one's own body, undetected. Such genes were practically alien to one's manifested qualities. ${ }^{49}$ Third, especially in eugenic discourse, recessive pathological genes were often treated as if they were independent entities - recall Jennings' 'living self-perpetuating creatures' - that were themselves defective; people with genetic ailments were thus contaminated by their own genes, or 'germinally affected' (keimkrank). ${ }^{50}$ Mutant, often hidden, and with an agency of their own, pathological genes

\footnotetext{
48 Scholars concerned with breeding and evolution (e.g. Hugo de-Vries, William Bateson) considered mutation as an ultimately favourable evolutionary mechanism. But writers who were preoccupied with human well-being commonly described mutations as genetic distortions resulting from poisons (alcohol) or unnatural interventions (extreme heat, radiation) and having mostly disadvantageous consequences. For example, compare R. Ruggles Gates, Mutations and Evolution (London: William Wesley \& Son, 1921) to Jennings, The Biological Basis, op. cit. (note 15), 321-2 and to Baur, Fischer and Lenz, op. cit. (note 6), 71-2, 395-7.

${ }^{49}$ See for example Hans F. K. Günther, Rassenkunde des deutschen Volkes (Munich: J. F. Lehmanns, 1923), 211-12; Karl Bareth and Alfred Vogel, Erblehre und Rassenkunde für die Grund- und Hauptschule (Bühl-Baden: Konkordia, 1937), 23.

50 The expression keimkrank is pervasive in German eugenic literature. See, for example, Arthur Gütt, Ernst Rüdin and Falk Ruttke, Zur Verhütung erbkranken Nachwuchses: Gesetz und Erläuterungen (Munich: J. F. Lehmanns, 1934).
} 


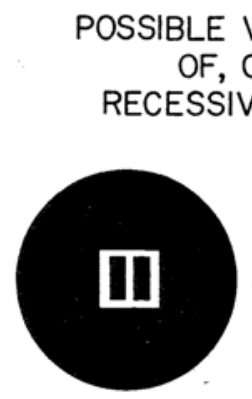

A

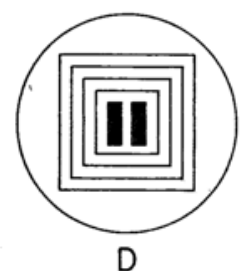

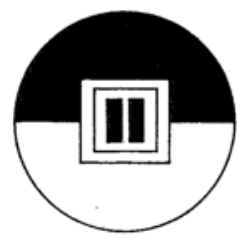

B

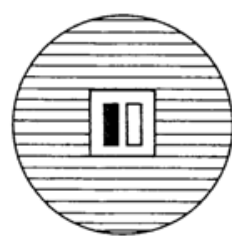

$E$

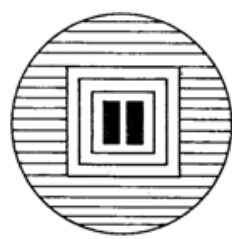

C

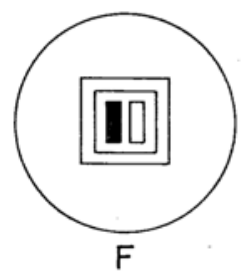

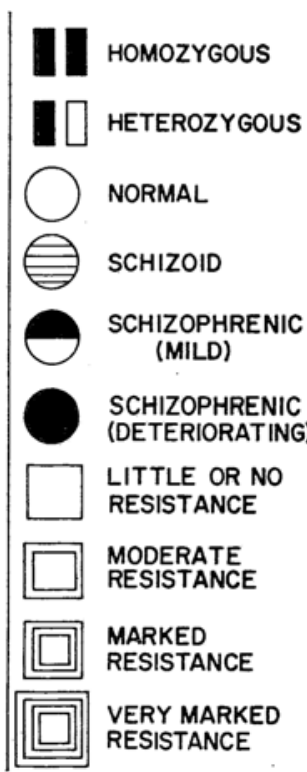

Figure 5: Constitutional resistance to genetic dispositions, as represented in a paper by psychiatrist Franz Kallmann, a student of the influential eugenicist Ernst Rüdin. According to the diagram, recessive genes for schizophrenia need to be blocked by a three-layered wall, or else their black-coloured effect will penetrate and contaminate the entire organism. Source: Franz J. Kallmann and S. E. Barrera, 'The Heredoconstitutional Mechanisms of Predisposition and Resistance to Schizophrenia', American Journal of Psychiatry 98 (1942), 544-50 (here 546).

were conceptualised as attacking or disrupting the functionality of the body - not from the outside, but from within (Figure 5).

Another means for alienating both germs and genes was by relating malignancy to foreign or alien races. In the case of germs, the age-old association of certain diseases with populations of outsiders (immigrants, the poor, 'racial others') fitted smoothly with the militaristic metaphors so common in bacteriological discourse, and assisted in legitimising policies of inspection, quarantine and closing of borders. If the cholera bacillus indeed came into Germany from 'the inner parts of Russia' and if other epidemic outbreaks were caused by 'Buddhist and Muslim pilgrims', then posing restrictions on immigration seemed entirely justified. ${ }^{51}$ Jewish immigrants in particular became a favourite target for mobilising first bacteriological discourse and later a racial-hygienic one in ways that often overlapped. This was true already in the early twentieth century, both in Imperial Germany as well as in America. ${ }^{52}$ Black bodies were also a frequent source of medical anxieties. A

51 The quotes are from Martin Kirchner, 'Die Verbreitung übertragbarer Krankheiten durch sogenannte "Dauerausscheider" und "Bazillenträger", in Klinisches Jahrbuch (Jena: Gustav Fischer, 1908), 473-82. For analysis, see Alan M. Kraut, Silent Travelers: Germs, Genes and the 'Immigrant Menace' (Baltimore, MD and London: Johns Hopkins University Press, 1994); Howard Markel and Alexandra Minna Stern, 'The Foreignness of Germs: The Persistent Association of Immigrants and Disease in American Society', Milbank Quarterly, 80, 4 (2002), 757-88; Andrea S. Lawson, 'The Association of Immigrants with Disease: Causes and Consequences' (unpublished PhD thesis: University of Western Ontario, London, Ontario, 2009); and further references below.

52 Since this topic has already been dealt with extensively in the research literature, I will not expand on this point here. See, however, Paul Julian Weindling, 'A virulent strain: German bacteriology as scientific racism, 1890-1920', in Waltraud Ernst and Bernard Harris (eds), Race, Science and Medicine, 1700-1960 
1905 American pamphlet called for the segregation of consumptives, warning that

As long as our colored people continue irregular habits, and herd together in immorality and dissipation, their homes will be hotbeds of infection, fresh from which they will enter into intimate relations with our white people, drinking from public cups, spitting around kitchens and public places . . . inevitably spreading infection broadcast among all classes. ${ }^{53}$

In a parallel manner, for those who considered mixture with foreign races a genuine social threat, the pathologising of foreign races went hand in hand with the alienation of those races' genes. 'Most of the recent immigrants,' stated American bacteriologist Thurman Rice in 1929, 'have come from eastern and southern Europe, and from other lands even less closely related; they do not mix with our stock in the "melting pot," and if they do cross with us their dominant traits submerge our native recessive traits .... 54 Amaurotic idiocy (Tay-Sachs) and diabetes soon became not only 'Jewish diseases' but also diseases that indicated the existence of Jewish genes and Jewish ancestral origin; similarly, sickle cell anaemia in a white individual immediately raised the suspicion of past intermixture with tainted 'colored blood' ${ }^{55}$ By implication, the genes presumably responsible for those pathologies turned into invaders, or polluters, of an otherwise healthy and pure national body.

\section{From Invisible Disease Agents to Undetectable Carriers}

The problem with germs and genes was not only their foreignness or invisibility. 'One of the most important discoveries of bacteriology,' explained Charles Chapin in 1917, head of Rhode Island's Public Health Department and one of the most influential health officials in America, 'and also one of the most disquieting [discoveries], is that the germs of most diseases are not confined exclusively to the sick, but are frequently found in well persons. ${ }^{56}$ The concept of the healthy carrier started taking shape in the last decade of the nineteenth century, after the cholera epidemic in Hamburg in 1892-4 indicated that there were people who, while exhibiting no indications for a disease, still distributed the malignant bacteria to others. ${ }^{57}$ Following the Hamburg epidemic, legislators in Prussia

(London: Routledge, 1999), 128-36 (quote from 132): 'Hereditary biology and bacteriology cross-fertilised with hatred of Jews as an alien culture and religion ... to generate a stereotype of the biologically immutable Jewish race as pathogenic'.

${ }^{53}$ Quoted in JoAnne Brown, 'Purity and danger in color: notes on germ theory and the semantics of segregation, 1885-1915', in Jean-Paul Gaudillière and Ilana Löwy (eds), Heredity and Infection: The History of Disease Transmission (London: Routledge, 2001), 101-31 (quote from 105). For another example, see Frederick L. Hoffman, Race Traits and Tendencies of the American Negro (New York, NY: Macmillan, 1896), 95.

54 Thurman B. Rice, Racial Hygiene: A Practical Discussion of Eugenics and Race Culture (New York, NY: Macmillan, 1929), quoted in Jonathan Marks, Human Biodiversity: Genes, Race, and History (New York, NY: de Gruyter, 1995), 85. For another example, see Egon von Eickstedt, 'Rassenelemente der Sikh. Mit einem Anhang über biometrische Methoden', Zeitschrift für Ethnologie, 52/53, 4/5 (1920), 317-94, especially 353, 378-79.

55 Shelley Z. Reuter, 'The Genuine Jewish Type: Racial Ideology and Anti-Immigrationism in Early Medical Writing about Tay-Sachs Disease', The Canadian Journal of Sociology, 31, 3 (2006), 291-323; Robert Singerman, 'The Jew as racial alien: the genetic component of American anti-Semitism', in David A. Gerber (ed.), Anti-Semitism in American History (Urbana: University of Illinois Press, 1986), 103-28; Arleen Marcia Tuchman, 'Diabetes and Race: A Historical Perspective', American Journal of Public Health, 101, 1 (2011), 24-33; Melbourne Tapper, In the Blood: Sickle Cell Anemia and the Politics of Race (Philadelphia: University of Pennsylvania Press, 1999); Keith Wailoo and Stephen Pemberton, The Troubled Dream of Genetic Medicine: Ethnicity and Innovation in Tay-Sachs, Cystic Fibrosis, and Sickle Cell Disease (Baltimore, MD: The Johns Hopkins University Press, 2006).

${ }^{56}$ Charles V. Chapin, How to Avoid Infection (Cambridge, MA: Harvard University Press, 1917), 18.

${ }^{57}$ Richard J. Evans, Death in Hamburg: Society and Politics in the Cholera Years, 1830-1910 (Oxford: Oxford University Press, 1987). The healthy carrier concept had some earlier forerunners; see for example Wilhelm 
began working on a law for combating diseases that 'posed a public danger'. ${ }^{58}$ According to the Prussian law passed in 1900 , externally healthy individuals who could potentially transfer a contagious disease could be subjected to restrictions of their rights, from requirement to report to the police on their whereabouts to curtailing their freedom of movement. In 1902 Koch publicly addressed the great epidemiological significance of human carriers of typhoid bacilli, and, as of the following year, bacteriological stations in Germany initiated investigations of carriers and their role in spreading disease. ${ }^{59}$

By 1908, German medical researchers had established that the problem of healthy carriers was not confined to cholera, but applied also to typhus, meningitis, diphtheria, amoebic dysentery and ancylostomiasis. ${ }^{60}$ Two years later, the British Local Government Board learned of the magnitude of the problem from an official report, news of which was published in Nature and The Hospital. ${ }^{61}$ The Nature paper enlightened its readers:

A 'carrier' ... is not merely a passive transmitter of infection; he is also a breeding-ground and storehouse of these specific organisms; and it appears that not only those sick with the fever, but also healthy persons who happen to be 'carriers' of the infection, offer the best explanation for the maintenance of the infection in communities. $^{62}$

On the other side of the Atlantic, American medical authorities established the idea of asymptomatic carriers with relation to diphtheria already in $1894 .{ }^{63}$ By the end of the following decade, the story of 'Typhoid Mary' - the Irish immigrant cook who was held in isolation for 26 years as a healthy, chronic carrier of typhoid bacilli - gave a considerable boost to the medical preoccupation with the new menace. By 1915, a Virginia physician related that 'all public health workers are of the opinion that a vast majority of all our communicable diseases are unquestionably due to carriers, we can account for them in no other way'. ${ }^{64}$ Another contemporary commentator was of the opinion that a healthy carrier was like

a Trojan horse[,] and his unsuspecting neighbors ... welcome him to their midst, and if their defences are impaired, welcome him to their sorrow. This great fact of human carriers of disease germs, about whom no

Griesinger, Infectionskrankheiten, Zweiter Band, Zweiter Abtheilung der Handbuch der speciellen Pathologie und Therapie, Redigirt von Rudolf Virchow (Erlangen: Ferdinand Enke, 1857), 251-4; C. F. Riecke, Die Reform der Lehre von den Contagion, Epidemien und Epizootien (Beiträge zur Staatsgesundheitspflege, 5. Theil) (Quedlinburg: H. C. Huch, 1854), 165. A succinct review of the development of the concept in the late nineteenth century is offered in Charles-Edward Amory Winslow, The Conquest of Epidemic Disease (Princeton, NJ: Princeton University Press, 1943), 337-46 ('Ch. XVI: The Concept of the Carrier').

58 Bundesarchiv Berlin-Lichterfelde (BArch), R86/4527: 'Entwurf eines Gesetzes, betreffend die Bekämpfung gemeingefährlicher Krankheiten, 24. 03. 1900', B1. 29-30.

${ }_{59}$ Robert Koch, 'Die Bekämpfung des Typhus. Vortrag gehalten in der Sitzung des wissenschaftlichen Senats bei der Kaiser Wilhelms-Akademie am 28 November 1902', in Veröffentlichung aus dem Gebiete des Militär-Sanitätswesens (Berlin: Hirschwald, 1903), XXI; P[aul] Frosch, 'Ueber regionäre Typhusimmunität', in Festschrift zum sechzigsten Geburtstage von Robert Koch (Jena: Gustav Fischer, 1903), 691-703; O[tto] Lentz, 'The Organization and Results of the Typhoid Campaign in South-West Germany', British Medical Journal, 2, 2602 (1910), 1501-3.

${ }^{60}$ See Kirchner, op. cit. (note 51), 473-82.

61 J. C. G. Ledingham, Report to the Local Government Board on the Enteric Fever 'Carrier': Being a Review of Current Knowledge on this Subject, Reports to the Local Government Board on Public Health and Medical Subjects, NS. 43 (London: Darling \& Son, 1910); (Eds), 'The Typhoid Carrier', The Hospital, 49, 1272 (1910), 314-16; (Eds), 'Enteric Fever Carriers', Nature, 85, 2144 (1910), 145.

62 Ibid.

63 Biggs, Park and Beebe, op. cit. (note 26), 7.

${ }^{64}$ Dr P. S. Schenk, Discussion of O. MacDaniel and E. M. Wade, 'The Significance of Typhoid Carriers in Community Life, with a Practical Method of Detecting Them', American Journal of Public Health, 5, 8 (1915), 765-73 (here 773). 
quarantine signs are evident, makes this subject of first importance. It is difficult to detect these individuals, and it is even more difficult to treat them when discovered. ${ }^{65}$

There is a clear conceptual continuum between the fear of invisible bacteria and the dread of undetectable bacteria-carriers. But when the preoccupation with invisibility shifted from the causal agents of disease to the transitory and chronic carriers of those same agents, a novel, and more nuanced, element emerged; namely, the fact that, from a public health perspective, small, barely manifest pathology was more disastrous than actual manifested harm. As Chapin phrased it in his above-mentioned lecture:

The bacteriologist has taught us another disquieting fact, namely, that in most of the contagious diseases there are many mild cases, so mild and with so few symptoms that they are almost sure to escape detection ... When a child is sick in bed with diphtheria, and everyone knows it, the danger of the disease spreading is not onetenth what it would be if the same child had a mild sore throat, not recognised as diphtheria, and was going to school and mingling with the other children in play ... Under modern conditions the known cases of contagious diseases are fairly well controlled. It is not from them that most disease comes, but from the carriers and missed cases. Neither you, nor I, nor the Board of Health, know where these are. ${ }^{66}$

During the same period, an identical idea was phrased with relation to inherited defects. Henry Goddard's famous study on the Kallikak family, which quickly became a cornerstone of eugenic thinking, explained that: 'A large part of those who are considered feeble-minded in this study are persons who would not be recognized as such by the untrained observer.' As Goddard saw it, when dealing with the challenge of feeblemindedness, 'the idiot is not our greatest problem ... It is the moron type that makes for us our great problem'. ${ }^{67}$ The distinction between 'a moron' and 'an idiot' applied by Goddard referred to three different grades of mental deficiency, wherein 'an idiot' was a person whose mental development was arrested at two years or less, 'an imbecile' at three to five years, and 'a moron' at eight to twelve years. In a paper on 'Feeblemindedness' published in 1915 by eugenicist Paul Popenoe, after evaluating the number of feeble-minded in the US, Popenoe similarly clarified that: "These figures refer only to feebleminded who can actually be distinguished as such - the "patent" individuals. The number of "latent" individuals, those not actually feebleminded themselves but carriers of the defect in their germ-plasm and capable of passing it on to their descendants, is necessarily vastly larger.' Importantly, 'while the grovelling idiot is unlikely to become a parent, the moron is almost certain to do so, either legitimately or illegitimately, unless prevented by society from doing so'. ${ }^{68}$ Worse still, such morons tended to bear many more children than either normative individuals or their idiot comrades.

Thus, just like Chapin's fear of the child with 'a mild sore throat, not recognized as diphtheria', for Goddard and Popenoe, the fact that 'the moron class shades off imperceptibly into the normal bulk of society', did not make such morons less harmful, but more so; the risk posed by their indistinguishability outweighed the fact that they were not that stupid after all. In the age of Mendelian genetics, the distinction between patent and latent individuals found its expression in the notion of recessive inheritance,

\footnotetext{
${ }^{65}$ Quoted from F. M. Meader's 'Treatment of the typhoid carrier, New York State Journal of Medicine (1912)', in Priscilla Wald, Contagious: Cultures, Carriers, and the Outbreak Narrative (Durham, NC: Duke University Press, 2008), 75.

66 Chapin, op. cit. (56), 18-20. Similarly, see Charles Chapin, Sources and Modes of Infection (New York, NY: Wiley, 1912), 93; Hill, op. cit. (note 22), 48; Biggs, Park and Beebe, op. cit. (note 26), 51.

${ }^{67}$ Henry Herbert Goddard, The Kallikak Family: A Study in the Heredity of Feeble-Mindedness (New York, NY: Macmillan, 1912), 100-1, 104.

${ }^{68}$ Paul Popenoe, 'Feeblemindedness', Journal of Heredity 6, (1915), 32-6 (quote from 36).
} 
which, from the early 1910s onwards, became strongly associated with diseases of various kinds, and specifically with mental defects. ${ }^{69}$ Later during the 1930s, in Nazi Germany, this conception of the destructiveness of small dangers effectively entered into the proceedings of the new Hereditary Courts, established to implement the 1933 Sterilisation Law. For example, in 1939, a Hereditary Court discussing a case of a man with a cleft lip, determined that 'precisely the light forms, from the standpoint of cultivating hereditary health, are the most dangerous ones, because their carriers reproduce more easily'. This was a common view. ${ }^{70}$

The assumption that mental depravity was hereditary, coupled with Mendelian notions of recessivity, gave rise to another concrete fear: the potential for unknowingly bringing about the homozygosity of malignant genes. Diane Paul has already analysed the debates among eugenicists on potential solutions to this problem..$^{71}$ One more example would nevertheless be useful to demonstrate the convergence of genetic concepts and cultural anxieties about the barely detectable. In their influential 1942 textbook Erbe und Schicksal (Heredity and Fate), the Nazi auxiliary school educators Karl Tornow and Herbert Weinert explain the nature of recessive inheritance as follows:

We know that recessive inheritance is particularly dangerous. It can easily deceive us; for with recessive inheritance even healthy-looking persons have within them the disposition to disease. And when two persons know nothing about it and marry each other, the malady suddenly makes itself apparent again among their children.

Later in the same book, the authors turn to discussing those who were only slightly mentally retarded. Like Goddard and Popenoe before them, they argue that such people are especially dangerous because their deficiency is not immediately apparent. 'More than anyone else, those who are themselves mentally weak do not notice it. And so it comes about, that often a mentally weak man marries a mentally weak woman ... This is very bad for the poor children in such families, most of whom are again mentally weak.' In Tornow and Weinert's description, recessive inheritance and mental retardation are functionally almost identical; in fact, the mentally weak are described using the same adjective as the one used for recessive inheritance. Common to 'weak inheritance' (schwach [er] Erbgang) and those with 'weak mentality' (Geistesschwach) is their undetectability, which ultimately proves fatal. ${ }^{72}$

Racial discourse once again became relevant for such discussions; after all, the greater danger posed by those who could not be externally differentiated from their healthy surroundings was a recurring theme already in nineteenth-century racial thought. One need

\footnotetext{
${ }^{69}$ Initially, the opposite view seemed more likely: 'It is somewhat singular', wrote William Bateson in 1909, 'that nearly all the abnormal features ... that have yet been positively shown to follow Mendelian rules in man are dominant to the normal.' Bateson, op. cit. (note 5), 210. Within a few years the reverse seemed much more plausible. In 1912, a prominent German eugenicist, Fritz Lenz, asserted that 'the vast majority of hereditary diseases are grounded in recessive pathological dispositions'. Fritz Lenz, 'Über die idioplasmatischen Ursachen der physiologischen und pathologischen Sexualcharaktere des Menschen', Archiv für Rassen- und Gesellschaftsbiologie, 9, 5 (1912), 545-603 (quote from 597).

${ }^{70}$ Archive of the Max Planck Institute for Psychiatry, MPIP-GDA 140, a case from 10.2.1939 regarding Karl K. The Nazi sterilisation law named 'severe hereditary deformities' as grounds for forced sterilisation; commentators and judges made it clear that by 'severe' the lawmakers did not refer to the way the malady had actually expressed itself in an individual, but to its potential damage in future generations. See Gütt, Rüdin and Ruttke, op. cit. (note 50); Hans Luxenburger, op. cit. (note 24).

${ }^{71}$ Paul, op. cit. (note 12).

72 Karl Tornow and Herbert Weinert, Erbe und Schicksal: Von geschädigten Menschen, Erbkrankheiten und deren Bekämpfung (Berlin: Alfred Metzner, 1942), 94, 158, 185-6.
} 
only recall Thomas Carlyle's reference to the 'white skin and European features' of the Irish who 'cannot be prevented from circulating among us at discretion', or Louis Agassiz' description of the Negroes' pliability and 'proneness to imitate those among whom he lives', or finally the ceaseless preoccupation in Germany with the deceptive nature of assimilated Jews and Jewish Mishclinge. ${ }^{73}$ After 1880, such racial characterisations were coupled, first, with discussions on the 'microörganisms [that] cannot be trusted', and later with descriptions of the recessive genes that 'can deceive on the content of the hereditary qualities' ${ }^{74}$ Indiscernible racial others harboured undetectable malignant germs - and genes; evidently, both aspects of impalpability felt more hazardous than actual, noticeable deviances.

\section{The Failure of Top-Down Solutions and the Development of Medical Consciousness}

As we have seen, healthy (asymptomatic) carriers of germs and healthy (heterozygous) carriers of genes were conceptually very much the same. From a public health perspective (in the former case), and from a racial-hygienic perspective (in the latter case), these carriers presented a greater challenge to the health of the population, and it was they who needed to be contained if the transfer of the pathogens was to be stopped. To identify germ carriers (or 'distributors'), medical authorities used epidemiological detection measures, beginning with known outbursts of epidemics and then tracking their source. This process necessitated access to civil records of various kinds. The bacteriological stations established in South-West Germany as of 1904 were empowered 'to prosecute inquires on the spot with the local authorities, while access was granted them to police records, dispensary lists, the official death-notification statistics, etc.; and they were also allowed to obtain information from the clergy, the school teachers, and the midwives' ${ }^{75}$ Identifying gene carriers similarly relied on the use of those who were actually ill as inferred indicators as to the genetic make-up of blood relatives. According to the vision promulgated in 1911 by Rüdin, later to be implemented in his Department of Genealogy-Demography at the German Research Institute for Psychiatry, this required medical investigators be granted access to 'the records of the church (Parish registers) and civil registers, the police, the local communities, institutions for the poor, courts, schools, reformatories, institutes for the feeble-minded, for the drunkards, hospitals, military authorities etc' ${ }^{76}$

The pursuit of individual suspects on the basis of manifested cases, however, was

\footnotetext{
${ }^{73}$ Louis Agassiz's letter from 9 August 1863, cited in Stephen Jay Gould, The Mismeasure of Man (London: W. W. Norton \& Company, 1981), 48; Carlyle's quote is from his 1848 'Repeal of the Union', cited in Julie M. Dugger, 'Black Ireland's Race: Thomas Carlyle and the Young Ireland Movement', Victorian Studies, 48, 3 (2006), 461-85 (quote from 468); Sander L. Gilman, Jewish Self-Hatred: Anti-Semitism and the Hidden Language of Jews (London: John Hopkins University Press, 1990); Gilman, 'The Jewish nose: are Jews white? Or, the history of the nose job', in Laurence J., Silberstein and Robert L. Cohn (eds), The Other in Jewish Thought and History: Constructions of Jewish Culture and Identity (New York: New York University Press, 1994).

${ }^{74}$ Henry J. Nichols, Carriers in Infectious Diseases (Baltimore, MD: Williams \& Wilkins, 1922), 24; Otto Reche, Die Rassenmischung beim Menschen, Text zum Vortrag VII Mit 30 Bildkarten (Munich: J. F. Lehmanns, 1936), 4. 75 'The Typhoid Carrier', 314; Ledingham, op. cit. (note 61).

${ }^{76}$ Ernst Rüdin, 'Einige Wege und Ziele der Familienforschung, mit Rücksicht auf die Psychiatrie', Zeitschrift für die gesamte Neurologie und Psychiatrie, 7, 1 (1911), 487-585 (here 540). Similar visions were outlined also in Alois Alzheimer, 'Ist die Einrichtung einer psychiatrischen Abteilung im Reichsgesundheitsamt erstrebenswert?', Zeitschrift für die gesamte Neurologie und Psychiatrie, 6, 1 (1911), 242-246; Harry. H. Laughlin, Eugenical Sterilization in the United States (Chicago, IL: Psychopathic Laboratory of the Municipal Court of Chicago, 1922), 363-4.
} 
both insufficient and impractical for stemming the tide of the spreading pathogens. In Germany, bacteriological studies indicated that the ratio of those actually ill to those who carried pathogens without manifesting clinical symptoms, was in the range of 1:15-20. In other words, for every ill person there were fifteen to twenty who looked healthy but actually bred and spread the pathogens; identifying, seizing or isolating all of them was simply unrealistic. ${ }^{77}$ Prior to the development of biochemical methods that enabled the measurement of enzyme activity for the detection of heterozygous carriers, how could one similarly evaluate the number of carriers of genetic diseases? The HardyWeinberg equation provided an estimate - and an oddly similar one. The frequency of the major mental illnesses, such as schizophrenia, in the general population was circa $1 \%$. A short algebraic computation revealed that the percentage of carriers of the genes purportedly responsible for mental pathologies with such a frequency, was around fifteen to twenty times higher. ${ }^{78}$ Thus, just like in the case of meningitis or diphtheria, for every schizophrenic, there were fifteen to twenty carriers of 'schizophrenia genes' in the population. With respect to feeble-mindedness, the ratio was even worse: 'For every individual bearing two of the defective genes, there are about 30 normal individuals bearing one such gene.' 79

One potential solution to the challenge of healthy carriers, sought by bacteriologists and geneticists alike, was to find ways that would allow for their clinical identification. 'Some carriers show no clinical or pathological evidences at all and are really healthy, but the most important carriers are only apparently healthy, because, on careful examination, they do show signs or symptoms of local infection', explained Henry J. Nichols, a US Army medical officer in $1922 .{ }^{80} \mathrm{He}$ was referring to carriers of germs. The following year the geneticist R. Ruggles Gates similarly expressed his hopes that ' $[\mathrm{m}]$ ore accurate mental tests may make it possible to distinguish such heterozygous individuals from the fully normal members of the population' ${ }^{81} \mathrm{He}$ was referring to carriers of recessive genes (in this case, for feeble-mindedness). ${ }^{82}$

Another measure for preventing the further spread of disease germs was to focus attention on monitoring the critical points of passage - not the roots but the routes of infection. It was the task of the New Public Health 'deliberately to analyse the particular outbreak of the particular disease concerned; speedily to determine thus the exact route of infection actually responsible; and promptly to abolish or block that route' ${ }^{83}$ To achieve that goal, health authorities in New York began in 1916 to conduct annual tests for those working in the food and milk industries, and to issue health certificates for food handlers. This practice became compulsory in 1923, but was discontinued as of 1934, once it

\footnotetext{
77 Kirchner, op. cit. (note 51), 481. The Prussian parliament discussed these calculations and their implications; see BArch R86/976, 'Entwurf eines Gesetzes zur Ergänzung des Gesetzes vom 28. August 1905 betreffend die Bekämpfung übertragbarer Krankheiten', 3, 5 (fol. 13).

${ }^{78}$ Hans Luxenburger, 'Zur Frage der Anfechtung der Ehe wegen krankhafter Erbanlagen (Einige rechnerische Überlegungen)', Zeitschrift für psychische hygiene, 10 (1937), 185-9.

79 Jennings, The Biological Basis, op. cit. (note 15), 241.

${ }^{80}$ Nichols, op. cit. (note 74), 14.

${ }^{81}$ R. Ruggles Gates, Heredity and Eugenics (London: Constable, 1923), 159.

82 Similarly, see Goddard, op. cit. (note 67), 105, 109-16. Supposedly, carriers of recessive dispositions to mental illnesses such as schizophrenia were also mentally peculiar. See Diane B. Paul and Hamish G. Spencer, 'Did eugenics rest on an elementary mistake?', in Rama S. Singh, Costas B. Krimbas, Diane B. Paul and John Beatty (eds), Thinking about Evolution: Historical, Philosophical, and Political Perspectives (Cambridge: Cambridge University Press, 2001), 103-18; Paul, op. cit. (note 12).

${ }^{83}$ Hill, op. cit. (note 22), 40.
} 
was realised that such steps were impractical, uneconomical and inefficient; among other problems, individuals could easily become ill between one examination and the next. ${ }^{84}$ The eugenic equivalent saw statutes passed in several American states during the 1910s that demanded prospective spouses to be clinically examined and to pass laboratory tests (e.g. the Wassermann test, to rule out syphilis). ${ }^{85}$ This measure also proved both uneconomical and of limited practical value, encouraging future spouses to circumvent restrictions by wedding in a jurisdiction with no marriage laws or by avoiding marriage altogether. Some eugenicists nevertheless continued to advocate the use of marriage certificates, which were also to include a close inspection of individuals' extended kinship, to rule out the inheritance of malignant genes. This practice became mandatory in Germany in $1935 .^{86}$

Until either measure proved effective, the fact that there were so many germ/gene carriers around meant that relying solely on top-down, state-enforced measures of identification, isolation and sterilisation would simply not do. The Prussian parliament acknowledged in the early 1920s that 'isolating germ carriers, which in theory would undoubtedly have been the best, is impractical' ${ }^{87}$ The non-feasibility of an enforced solution generated a Foucauldian alternative: the responsibility for taking measures to avoid transmitting the pathogens was transferred to those who could suspect themselves of carrying malignant germs/genes. In this respect, the role of doctors and of the medical establishment was not only to monitor, detect, prevent and heal, but primarily to awaken the carriers' feelings of obligation, so that they would regulate their own medical, social and reproductive behaviour. Instructions handed out to typhoid carriers in Germany thus emphasised that it was 'morally incumbent on carriers' to adhere to habits of cleanliness that were necessary to avoid infecting others. ${ }^{88}$ 'There is no doubt,' explained the head of the Institute for Hygiene and Bacteriology at Gelsenkirchen (a city in today's North RhineWestphalia), 'that the fact that a person knows he is a carrier of germs raises substantially his feeling of responsibility for his family and fellow men. ${ }^{89}$

Various historians have already pointed out that such appeals to the responsibility of the carriers to avoid infecting others were often accompanied by a host of middle-class ideals of cleanliness and norms of cultured behaviours, epitomised by the American crusade against spitting in public. It was the 'incorrigible ... indiscriminate spitter, the drunkard,

${ }^{84}$ William H. Best, 'Is Routine Examination and Certification of Food Handlers Worth While?', American Journal of Public Health, 27, 10 (1937), 1003-6.

85 Oscar Dowling, 'The Marriage Health Certificate, A Deeply Rooted Social Problem', The American Journal of Public Health, 5, 11 (1915), 1139-44; Walter Taylor Sumner, 'The health certificate - a safeguard against vicious selection in marriage', in Proceedings of the First National Conference on Race Betterment, Battle Creek, Michigan (Race Betterment Foundation, 1914), 509-15; S. Adolphus Knopf, 'Some suggestions for a more rational solution of the tuberculosis problem in the United States', in ibid., 113-36. For an overview and analysis, see Christine Allison Stolba, 'A Corrupt Tree Bringeth Forth Evil Fruit: Religion and the American Eugenics Movement' (PhD thesis: Emory University, 1999), 129-55; Philip K. Wilson, 'Bad Habits and Bad Genes: Early 20th-Century Eugenic Attempts to Eliminate Syphilis and Associated "Defects" from the United States', Canadian Bulletin of Medical History, 20 (2003), 11-41; Paul A. Lombardo, 'A Child's Right to be Well Born: Venereal Diseases and the Eugenic Marriage Laws, 1913-1935', Perspectives in Biology and Medicine, 60, 2 (2017), 211-32.

86 On Laughlin's advocation of pedigree analysis, see Wilson, ibid., 30. On Germany, see Paul Weindling, Health, Race and German Politics Between National Unification and Nazism: 1870-1945 (Cambridge: Cambridge University Press, 1989).

${ }^{87}$ BArch R86/976, Entwurf eines Gesetzes betr. die Bekämpfung sonstiger einheimischer übertragbarer Krankheiten, 1923 discussion, B1. 3.

${ }^{88}$ Ledingham, op. cit. (note 61), 123-4 (Verhaltungs-Massregeln für Typhusbazillenträger).

${ }^{89}$ Hayo Bruns and Josef Hohn, 'Über den Nachweis und das Vorkommen der Meningokokken im Nasenrachenraum', in Klinisches Jahrbuch (Jena: Gustav Fischer, 1908), 285-310 (here 308). 
the filthy ... [who] belong to the large class of socially irresponsible and have to be dealt with by disciplinary methods ... the enforcement of order must be based on broad hygienic ethical and legal principles,' explained the expert on Tuberculosis Arnold C. Klebs in $1918 .{ }^{90}$ Nichols, the US Army medical officer, argued that when a carrier 'does not respond to social obligations, restrictive measures must be applied'. ${ }^{91}$ 'The individual [carrier] should recognize his social obligations ... If he is unwilling to accept this point of view he may be forced to it. ${ }^{92}$ The Primer of Sanitation, intended for a younger readership, used even stronger language: 'No thief thinks well of the policeman who arrests him, and no murderer loves the judge who sentences him to be hanged. So the persons who are compelled to clean up their premises and live so that they will not be a nuisance and a source of danger to their neighbours often become angry with the health officials ... deliberately to scatter abroad disease germs is a crime, and the man who does it knowingly deserves to be treated as other criminals are treated. ${ }^{93}$

But these implicit threats of force were a rhetoric of morality, not a plan for action. And since they could not realistically materialise on a mass scale, it was propaganda, education and social sanctions that were employed in the fight against germ distributors, those careless violators of good taste and public order. ${ }^{94}$ 'In the absence of power to exclude the carrier from such occupations [in the milk industry],' explained the preface to Ledingham's Report to the British Local Government Board, 'endeavour should be made to attain this end by persuasion, and, in the event of failure to persuade, to secure the

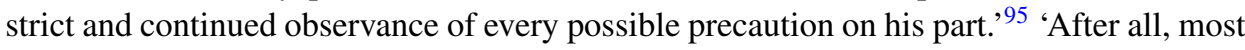
families suffer from germ diseases more because of their own carelessness than because of the faults of others,' the Primer of Sanitation reminded its readers. ${ }^{96}$ Yet at the same time, 'As physicians and citizens we need to realize, once for all,' argued Nichols, 'that while in some respects the individual is an ultimate unit, in others, he is only a part of higher units, the family, the community, and the nation, and he cannot exist without them. Hence, medically as well as biologically, the interests of the whole, that is, of the race, are greater than those of the individual parts.' What made such a pronouncement necessary, from Nichols' perspective, was bacteriology, and particularly, the role of carriers in individual and social medicine. ${ }^{97}$

The same kind of appeal to the interests of the larger biological whole was germane to eugenically imbued genetics. Here, too, talk of individual responsibility reigned in discussions of inherited medical pathologies. For instance, in 1920, the Berlin Society for Racial Hygiene worked on compiling information sheets for those planning to marry.

90 Arnold C. Klebs, 'The Tuberculosis Problem: One Point of View', The American Review of Tuberculosis, 2, 2 (1918), 106-8, quoted in Jeanne E. Abrams, “"Spitting Is Dangerous, Indecent, and against the Law!": Legislating Health Behavior during the American Tuberculosis Crusade', Journal of the History of Medicine and Allied Sciences, 68, 3 (2013), 416-50.

91 Nichols, op. cit. (note 74), 24.

92 Ibid., 37.

93 John W. Ritchie, Primer of Sanitation, Being a Simple Work on Disease Germs and How to Fight Them (Yonkers-on-Hudson, NY: World Book Company, 1911), 173-4.

${ }^{94} \mathrm{See}$ also in this respect Brown, op. cit. (note 53). As Weindling has argued with relation to the bacteriological revolution of the $1880 \mathrm{~s}$, 'The liberal belief in the individual's responsibility for personal health became reformulated in collectivist terms of the health of the family and of future generations'. Weindling, op. cit. (note 86), 158.

95 Theodore Thomsom, 'Preface', in Ledingham, op. cit. (note 61), 3.

96 Ritchie, op. cit. (note 93), 191.

${ }^{97}$ Nichols, op. cit. (note 74), 18, 39. 
All of the drafts prepared by the members of the society emphasised that individual health, and even one's own body, were not personal, individual possessions, and that marital choices should express one's responsibility for future generations. This responsibility, however, could not be taken by the marriage partners alone, if only because they could never know if they were truly healthy: 'Only a doctor can say whether disease exists ... Many are sick without knowing. ${ }^{98}$ Another draft similarly reminded its potential readers, 'No-one knows, whether he is so healthy that he could not transmit or inherit a disease or disease-factor in the family. Only a medical examination can determine that with certainty.' A third draft straightforwardly advised prospective marriage partners: 'Go to a doctor whom you trust, and let him prove, whether you are healthy.' The eventual pamphlet piled up all these warning one on top of the other. Sliding from an appeal to one's morality to explicit threats for sanctions against those who ignored medical advice, it made perfectly clear that the responsibility for not transferring bad genetic material did not engender a range of legitimate courses of action. On the contrary, it was one's responsibility to do precisely what the doctors advised, but could not enforce. The duty to discipline and punish was one's own, and misconduct, while not yet punishable, was to be socially sanctioned by the stigma of 'irresponsibility', or even egoism, of those who did not follow the medical dictum and allowed themselves a free rein, thus putting their fellow compatriots in danger. ${ }^{99}$

The transfer of responsibility for self-surveillance to the individual citizens was, however, neither a result of, nor an indication for, the immense power of the state or its medical authorities to shape the bio-political order to serve their purposes and increase their power, a la Foucault. On the contrary: it was an indication of the medical profession's incompetence, or inability, to cope with the proliferation of innumerable, undetectable pathogenic agents. It was bio-impotence, not bio-power; a sign of losing control, not its exertion.

\section{Reincarnations of the Female Carrier}

Mary Mallon, or 'Typhoid Mary' as she became known, is the most salient embodiment of the early twentieth-century fear of contagion through seemingly healthy individuals. Mary's iconic status had much to do with her social attributes as an Irish immigrant, a lower-class servant and a single woman. All of these features, together with her refusal to accept her responsibility and her denial of the validity of bacteriological science in general, greatly contributed to the harsh treatment she received from the health authorities of New York. The 8 May 1915 issue of Scientific American referred to 'her perversity ... She has never conceded herself a menace; she has not obeyed the sanitary directions given her; she would not wash and disinfect her hands as required; she will not change

\footnotetext{
98 BArch R/86 5626, Denkschrift des Ministeriums für Volkswohlfahrt über die Frage der Forderung von Gesundheitszeugnissen vor der Eheschließung, Feb. 1922, B1. 25-6: Merkblatt für Eheschliessende; BArch R/86 5623, Merkblatt für Eheschliessende, B1. 1, 8. For excerpts of the eventual form and relevant context, see Asmus Nitschke, Die 'Erbpolizei' im Nationalsozialismus: Zur Alltagsgeschichte der Gesundheitsämter im Dritten Reich (Opladen/Wiesbaden: Westdeutscher Verlag, 1990), 43.

99 At least in Germany, the internalisation of this message by the public is evidenced in sterilisation candidates' own pleadings. For example, a sterilisation candidate argued in 1939 that 'My 4-year child-less marriage can prove my awareness of my responsibility' (Landesarchiv Berlin A Rep. 042-08-01 Nr.5499, case of W. A., epilepsy). Further examples can be found in Gisela Bock, Zwangssterilisation im Nationalsozialismus (Opladen: Westdeutscher Verlag, 1986), 160, 163, 184, 211, 299, 311, 397, 422, 426, 456.
} 
her occupation for one in which she will not endanger others' ${ }^{100}$ Judith Leavitt pointed out that men (or, male breadwinners) who were thought to have spread typhoid germs to at least as many individuals as Mary Mallon received much more lenient treatment from medical authorities. Leavitt argued that the fears raised by Mary tapped into prevalent anxieties that were associated with Mary's sexuality and female qualities, her cooking, and her uncleanliness. ${ }^{101}$

Taking the argument one step further, literary scholar Priscilla Wald convincingly demonstrated that the anxieties raised by Mary as a female carrier were themselves a reincarnation of a prior, prevailing cultural configuration of women as distributors of venereal diseases. The promiscuous woman, the single woman, the New Woman, the lightheaded, 'fallen girl', the servant and the prostitute, were all manifestations of the fear of women's transgression of sexual and moral boundaries, a transgression that was doomed to ruin society as a whole. ${ }^{102}$ These fears found their medical confirmation in the study of syphilis, gonorrhoea and other sexually transmitted diseases, all transferred by innocentlooking females to an unsuspecting (and far from morally upright) male partner, then to his innocent lawful wife, and finally, following the wife's pregnancy, to a deformed or blind baby. 'You know,' explained an obstetrician in a Berlin clinic in 1927, 'that there are women who know nothing about their infection, and only become aware of it once they give birth to a dead child. You know furthermore that there are women that know about their infection but leave it entirely or incompletely untreated, because they have no signs of it. ... Mothers, that perhaps know nothing about their disease, or think they are healed, do not put their children under medical control.' 103

A 'racial poison' that 'strikes at the pure home and the wholesome marriage', syphilis was the quintessential meeting point for fears of moral and physical decay. ${ }^{104}$ Although the cultural figure of the promiscuous woman as dispersing diseases predated the bacteriological revolution, it was swiftly adapted to discussions of unruly female behaviour as germ-distributing. Charles Chapin, in his earlier mentioned lecture, warned of the spread of diseases through women's kisses: 'Gushing women, who kiss their neighbor's children, and schoolgirls who use this salutation as freely as a shake of the hand, should learn that this meaningless use of the kiss disregards the canons of good taste, as it certainly does sanitary precepts.' 105 Not only through their sexual organs, but also through their daily gestures, women spread disease.

Worse still, women also distributed bacteria as cooks, waitresses, housekeepers, servants or even bakers' or shoemakers' wives. Statistical surveys confirmed that in the case of certain diseases, such as typhoid fever, more women than men were chronic bacteria carriers. ${ }^{106}$ On the very first pages of his 1913 book, The New Public Health, the director

\footnotetext{
100 'Typhoid Fever', Scientific American (8 May 1915), 428.

101 Judith Walzer Leavitt, Typhoid Mary: Captive to the Public's Health (Boston, MA: Beacon Press, 1996).

102 Wald, op. cit. (note 65).

103 Humboldt Universität Berlin, Universitätsarchiv, Hyg. Inst. 165, draft for a talk by Priv.-Doz. Dr Ernst Philipp, in connection with the 1927 Law for Combating Venereal Diseases. See similarly Thurman B. Rice, The Conquest of Disease (New York, NY: Macmillan, 1928), 298-300; Prince A. Morrow, Social Disease and Marriage (New York, NY: Lea Brothers, 1904).

104 Rice, ibid., 298-300; Mary Spongberg, Feminizing Venereal Diseases (New York: New York University Press, 1997); Peter Baldwin, Contagion and the State in Europe, 1830-1930 (Cambridge: Cambridge University Press, 1999), 543; Roger Davidson and Lesley A. Hall (eds), Sex, Sin and Suffering: Venereal Diseases and European Society since 1870 (London and New York, NY: Routledge, 2001).

105 Chapin, op. cit. (note 56), 39-41.

${ }^{106}$ Heinrich Kayser, 'Über die Gefährlichkeit von Typhusbazillenträgern', in Beiträge zur Bekämpfung des
} 
of the Division of Epidemiology at the Minnesota State Board of Public Health rhetorically inquired, 'Who keeps the infectious disease going?' He did not leave his readers in much suspense: 'Once more the answer is - and most emphatically - women in general, but chiefly after all the mother.' It was 'mothers [who] propagate and keep alive and spread the infectious diseases of children more than any other one body of people ... The infectious diseases in general radiate from and are kept going by women'. ${ }^{107}$

Mendelian genetics provided its own formulation for the female carrier infecting her children with disease: it was called sex-linked inheritance. The realisation that sex was determined genetically by a simple Mendelian mechanism - females having two $\mathrm{X}$ chromosomes, males one $\mathrm{X}$ and one $\mathrm{Y}$ - paved the way for the idea that defects on either of these chromosomes would result in peculiar distributions of genetic diseases among men and women. Of the three possible forms of sex-linkage - Y-linked, X-linked dominant and $\mathrm{X}$-linked recessive - it was the latter that received most attention, and that could explain well-known curiosities, like the inheritance of haemophilia and colour-blindness. ${ }^{108}$ Although their overall medical significance was marginal (colour-blindness was of minor functional importance; haemophilia was rare, but famous through its association with British royalty), the ability to account for these peculiarities enhanced the appeal of Mendelian theory in general, extending its explanatory power to seemingly irregular distributions of disorders and providing the key to riddles that had long preoccupied the minds of medical scholars. ${ }^{109}$

In addition to this, sex-linked inheritance gave genetic thinking its own version of the female-carrier peril. The 'sex-linked' nomenclature itself was ambiguous: on the one hand it was used interchangeably with X-linked. ${ }^{110}$ At the same time, at the phenotypic level, it implied that the trait under discussion was associated with only one of the sexes, and in the case of haemophilia or colour-blindness, one might except it to have been the male one. 'How does one recognize sex-linked inheritance?', asked Tornow and Weinert in their textbook of heredity. And they answered: 'In sex-linked inheritance, the disease expresses itself in the male sex. The female sex is usually only the transferring agent and is externally healthy. ${ }^{, 11}$ If the disease exhibited itself among males, was it then 'linked' to the male sex? Judging by Tornow and Weinert, the answer was negative: 'the hereditary disposition

Typhus im Deutschen Reiche (Arbeiten aus dem Kaiserlichen Gesundheitsamte, 24. Band), (Berlin: Julius Springer, 1906), 176-80; J. C. G. Ledingham and J. A. Arkwright, The Carrier Problem in Infectious Diseases (London: Edward-Arnold, 1912), 30-6; Lentz, op. cit. (note 59), 1502: 'About 75 per cent. of all typhoid carriers are adult women'; Frederick G. Novy, 'Disease Carriers', Science, 36, 914 (1912), 1-10 (5: 'Women are the most prone to this condition'); Nichols, op. cit. (note 74), 45: 80\% of carriers are female.

107 Hill, op. cit. (note 22), Preface.

108 There were also biological factors contributing to the belated and minimal scholarly attention given to the Y-linkage, having to do with the dimensions of the Y chromosome itself, which contained significantly fewer genes than the $\mathrm{X}$ chromosome and influenced traits of minor significance, such as hairy ears. For a review of the early literature on the topic, see Curt Stern, 'The Problem of Complete Y-Linkage in Man', The American Journal of Human Genetics, 9, 3 (1957), 147-66.

109 See, for example, Ernst Rüdin, 'Einige Wege und Ziele der Familienforschung, mit Rücksicht auf die Psychiatrie', Zeitschrift für die gesamte Neurologie und Psychiatrie, 7, 1 (1911), 487-585, especially 508. On haemophilia, see Stephen Gregory Pemberton, The Bleeding Disease: Hemophilia and the Unintended Consequences of Medical Progress (Baltimore, MD: Johns Hopkins University Press, 2011).

110 'Sex-linked' formally meant that genes were carried by the sex-determining chromosome, whose double dosage resulted in females, and whose absence was a prerequisite for maleness - that is, by the $\mathrm{X}$ chromosome. See Thomas Hunt Morgan and C. B. Bridges, Sex-Linked Inheritance in Drosophila (Washington, DC: Gibson Brothers, 1916), 7-9.

111 Tornow and Weinert, op. cit. (note 72), 97, 222-3. 
to haemophilia is namely tightly-bound to the hereditary disposition for [producing] a girl. ${ }^{112}$

One did not have to be a Nazi educator to formulate the issue that way. As early as 1909, William Bateson explained with relation to haemophilia and colour-blindness, along with Gower's disease and night-blindness: 'They affect males much more commonly than females ... They are nevertheless transmitted by the unaffected females. Apparently normal women, sisters of the affected males, thus may transmit the condition to some of their sons. ${ }^{113}$ Three years later, the British Treasury of Human Inheritance analysed the mode of transmission of haemophilia: 'the disease is transmitted by the unaffected female - the "conductor".' How could it be, therefore, that sick fathers occasionally bore sick sons - with no intermediate female conductors? The answer was that due to intermarriages in small communities, 'a woman presumably normal, but in reality a "conductor," may marry a man in a bleeder family and be responsible for his bleeder sons.' 114

The 1911 novel of the prolific Swiss author Ernst Zahn, The Women from Tannò, gave popular literary form to these ideas. The plot tells the story of an isolated village community struck by haemophilia. Only by convincing women to control and extinguish their sexual desires could the spread of the disease be stemmed. Unfortunately, repressing their passions only made these women more attractive; one of the female protagonists seduced a man and deviously conspired to deceive her fellow villagers by wedding him with another, non-carrier woman while continuing the affair with him. A doctor who visited the village thought that, ultimately, a law should prohibit these women's further reproduction. ${ }^{115}$

Bateson's and Zahn's 'apparently normal women', Mary Mallon who was the 'most harmless and yet most dangerous woman in America', 'a living, walking incubator of typhoid fever germs' and the syphilitic women who 'know nothing about their infection, and only become aware of it once they give birth to a dead child', were all descriptions grounded in bio-medical realities. At the same time, they were all cultural configurations of a common theme, which transformed women's sexual behaviour into a public medical danger. Once in place, one gendered policy provided justification for another. 'A disease that is transmissible, whether by a micro-organism or by the germ cells, at once becomes a public health problem', explained Madge Thurlow Macklin, a clinical researcher and one of the founders of the Canadian Eugenics Society, in 1932. 'If we make a typhoid carrier give up her job as a cook, isolate her ... and keep her practically a prisoner until she is rendered incapable of transmitting her disease, are we not justified in isolating and rendering incapable of transmission a person who infects not a few with whom he comes into contact, but the whole future race descended from him?'116

\footnotetext{
112 Ibid., 83.

113 Bateson, op. cit. (note 5), 223.

114 William Bulloch and Paul Fildes, 'Section XIV: haemophilia', in Karl Pearson (ed.), Treasury of Human Inheritance, 1 (London: Dulau and Co., 1912), 169-354 (here 184).

115 Ernst Zahn, Die Frauen von Tannò (Stuttgart and Leipzig: Deutsche Verlags-Anstalt, 1911). I thank Ralph Müller (Friborg) for his advice regarding Zahn.

116 Madge Thurlow Macklin, 'Should the Teaching of Genetics as Applied to Medicine have a Place in the Medical Curriculum?', Journal of the Association of the American Medical Colleges, 7 (1932), 368-73 (quotes from 371-2).
} 


\section{Conclusion}

One of the defining features of Mendelian genetics - and, retrospectively, one of its scientific breakthroughs - was its consideration of each and every trait - and malady independently. Early twentieth-century genetics did not aspire to explain how an entire variety of a plant species, or the overall shape of the foot, along with their organic or physiological structures, were inherited; it focused on malformations, such as an extra finger, and malfunctions, such as colour-blindness or albinism, or at most specific traits, such as eye or pea colour. In 1865, compared with previous strands of hereditarian thought, this presented a radical shift, which is often explained by reference to Mendel's foresight or more generally to the atomistic spirit of the time. ${ }^{117}$ Translated into medical parlance: whereas much of nineteenth-century hereditary thought dealt with the inheritance of general predisposing causes (neuropathic constitution, diathesis), Mendelian genetics revolved around the inheritance of particulate exciting causes (genes). The enthusiastic endorsement of Mendelism among (some) medical professionals after 1900 can be better understood when set against the simultaneous rise of medical bacteriology, which also moved from general, environmental, miasmatic explanations to particulate, specific and concrete bacteria as causes of diseases. One did not have to wait to the 1990s for genetics to 'align perfectly with the old germ theory model and ... fuel the acceptance of genetics in medicine and in society', as Peter Conrad has suggested. ${ }^{118}$

Furthermore, building on common epistemological assumptions had inevitable implications for the mutual shaping of medical genetics and medical bacteriology. Some of these have been noted in the past. Charles Rosenberg once observed: 'the period of most enthusiastic hereditarianism - let us say the years between 1885 and 1920 - coincided with the most enthusiastic and uncritical acceptance of the germ theory.' With the notable exception of tuberculosis, the diseases that the former could explain were distinct from the ones dealt with by the latter. Nevertheless, '[w] hat hereditarian thought and the germ theory had in common was their ability to provide material and increasingly reductionist answers to the problems of human individuality and pathology'. ${ }^{119}$ Reductionism and materialism indeed provided similar theoretical premises to both theories; both germ theory and gene theory presupposed that the root of disease lay not in the physical, individual body, but in some other tiny and transferable cellular entity.

It is noteworthy that in retrospect, the reductionist approach underlying bacteriology was never tainted the way that reductionist-genetics was. On the contrary: the application of germ theory to tackle the greatest disease threats of the late nineteenth and early twentieth century is widely celebrated as a triumphant success story, with proven positive results in the eradication of widespread epidemics. Compared to these achievements, the socially problematic implications of germ theory may seem marginal. ${ }^{120}$ Even the use of medical

\footnotetext{
117 See Garland E. Allen, 'The classical gene: its nature and its legacy', in Parker and Ankeny, op. cit. (note 18), $11-41$.

118 Conrad was on the right track when he remarked that the reasons for the affinities he had identified between contemporary genetics and germ theory should be sought in genetics' past: 'It is as if a classic Mendelian model of genetics prevails in the popular discourse.' See Conrad, op. cit. (note 13), 233.

119 Charles E. Rosenberg, 'Heredity, the bitter fruit: heredity, disease, and social thought', in No Other Gods: On Science and American Social Thought (Baltimore, MD and London: The Johns Hopkins University Press, 1978), 35.

${ }^{120}$ Paul Weindling noted twenty years ago: 'the history of bacteriology has traditionally been conceived of in value-neutral terms. ... The political cultures nurturing the growth of bacteriology have often been overlooked in favour of more value-neutral explanations. Being grounded in experimental biology, bacteriology and the rise
} 
advances as 'Tools of Empire' and the colonialist nature of 'Tropical Medicine' did little to harm the aura of bacteriological theory itself. ${ }^{121}$ One reason for that is that, whereas the relations between Mendelism and eugenics relied on, and reinforced, essentialist, reductionist and deterministic genetic notions, the experiences of European doctors in India, Africa and elsewhere led in the opposite direction - namely, to the challenge, and later development, of bacteriological theory, to opening up new fields of research (e.g. parasitology), to new aetiological components (e.g. intermediate vectors such as the mosquito, the louse) and to the introduction of novel concepts (e.g. inapparent infection).

Yet at the same time as these developments took place, and regardless of them, some of the concepts that indicated the complex dynamics and interactive nature of disease processes also contributed to strengthening the focus on one side of the aetiological equation. By allowing for practically unlimited leeway in the actual expression of disease symptoms among those carrying the disease agents, theoretical crutches like virulence and penetrance helped to explain away empirical inconsistencies and maintain an essentialist, reductionist theoretical position in both fields. Moreover, by defining virulence/penetrance as properties of the germs/genes themselves, both concepts transformed phenotypic variability into a bacterial/genetic one and retained the analytic and aetiological focus on those presumed causal agents, as opposed to their hosts or to the interaction between the two.

In their basal forms, both bacteriology and genetics therefore implied a secondary role to environmental and individual factors in the causation of disease; as a corollary, both also diminished the importance of ameliorating social factors, such as working and living conditions, for safeguarding population health. In this sense, in addition to epistemological affinities, shared socio-political circumstances were also important. Müller-Wille and Rheinberger mention briefly that 'the intense interest in heredity around 1900 has to be seen [against] the increasing socialization and politicization of medicine'. During this time, 'disciplines that focused on whole populations as their subject, such as demography, epidemiology, hygiene, and social medicine, emerged and would soon receive growing resources', and this fact prepared the professional and institutional groundwork that would later propel genetics' prominence. ${ }^{122}$ Undoubtedly, the emphasis on studying and healing entire populations is another reason underlying some of the similarities between bacteriology and genetics noted above, and could partially explain the focus on transmission, rather than the individual remedy of disease. Since in their early

of germ theory have been seen as antithetical to social and racial ideologies.' See Weindling, op. cit. (note 52), (quote from 128); Weindling, Epidemics and Genocide in Eastern Europe, 1890-1945 (New York, NY: Oxford University Press, 2000). For an American example of the racist impact of bacteriology, see Brown, op. cit. (note 53).

${ }^{121}$ Daniel R. Headrick, The Tools of Empire: Technology and European Imperialism in the Nineteenth Century (Oxford and New York, NY: Oxford University Press, 1981); David Arnold (ed.), Warm Climates and Western Medicine: The Emergence of Tropical Medicine, 1500-1900 (Amsterdam - Atlanta: Rodopi, 1996); Kim Pelis, Charles Nicolle, Pasteur's Imperial Missionary: Typhus and Tunisia (Rochester, NY: University of Rochester Press, 2006); Deborah J. Neill, Networks in Tropical Medicine: Internationalism, Colonialism, and the Rise of a Medical Specialty, 1890-1930 (Stanford, CA: Stanford University Press, 2012).

122 Müller-Wille and Rheinberger, op. cit. (note 8), 96-7. These authors' comments rely primarily on two studies by Mendelsohn and Christophe Bonneuil, who point at intriguing and usually overlooked influences that the work of Koch and Pasteur had on the rise of genetics; these relate mainly to the preoccupation with purification, standardisation of crops, and the production of pure cultures. See Christophe Bonneuil, 'Pure lines as industrial simulacra: a cultural history of genetics from Darwin to Johannsen', in Müller-Wille and Brandt, op. cit. (note 17), 213-42; J. Andrew Mendelsohn, 'Message in a bottle: vaccines and the nature of heredity after 1880', in ibid., 243-64. 
Anglo-Saxon versions, both bacteriology and genetics oriented themselves towards healing supra-individual entities - a family, a society, a nation, a race - both strengthened the role of the state in diagnosing, intervening and maintaining medical order, at times even at the expense of individual rights. ${ }^{123}$

As we have seen, however, the affinities do not end there. There were additional similarities that stemmed from both fields' mutual roots in botany, ${ }^{124}$ and from the resulting common properties in the objects of study themselves and in the methods available at the time for depicting them; or that sprung from shared cultural anxieties and social premises; or that originated from similar institutional frameworks, or pointed to the reliance on a common language or even imagination, for describing and coping with medical harms. Despite the time lag between Koch's and Pasteur's discoveries and the rise of early Mendelian genetics, some of the core concepts shared by both theories evolved simultaneously; as we have seen, most conspicuous among these was the concept of carrier, with its many ramifications for public medicine, morality and the responsibility of women. ${ }^{125}$

One can also find cases of direct influence - of scholars who explicitly drew on methods and concepts from one field and applied them to the other. ${ }^{126}$ There were also areas of intersection between bacteriology and genetics, such as the question of the evolution of bacterial species, through which the notion of mutation was first introduced into medical bacteriology. These direct links, however, were rather marginal and the questions they raised remained largely unexplored until the 1950s. ${ }^{127}$ Long before the fields began to move towards each other, however, they already shared many essential elements. As products of the same era and of similar cultures, it may indeed seem unsurprising that both theories, and the hygienic principles they enshrined, shared so many features. That many of these similarities have thus far evaded our scrutiny testifies primarily to our own historiographical biases.

\footnotetext{
${ }^{123}$ In this respect, too, French medicine was different; as Thomas D. Brock observed in Robert Koch: A Life in Medicine and Bacteriology (Washington, DC: American Society for Microbiology, 1999), 177: 'Pasteur's approach was to treat individuals whereas Koch's approach was to treat populations'.

${ }^{124}$ It is remarkable that the same historical figure - Swiss botanist Carl von Nägeli - plays a very similar (negative) role in the rise of the two research fields. Infamous as the man who undermined the significance of Mendel's cross-pollination experiments (and thus supposedly hindered Mendel from fully grasping the significance of his own theory), Nägeli also objected to Koch's propositions on the constancy and specificity of bacteria, claiming instead that bacteria were both morphologically and functionally pleomorphic. That this dual role of Nägeli has never been noted is emblematic of the historiographical distance between the two fields.

125 In his dissertation on Cultures of Biology, Mendelsohn noted that ' $\mathrm{t}$ ] $\mathrm{he}$ two or three decades after 1905 can truly be called the golden age of the carrier'. Indeed they can, but this was true for both bacteriology and genetics (Mendelsohn referred to the former). Mendelsohn, op. cit. (note 11), 757.

${ }^{126}$ For example, Curt Stern observed that '[i]t is of historical interest that the terms penetrance and expressivity were introduced by an investigator [Oscar Vogt] whose main work was related to medicine'. See Laubichler and Sarkar, op. cit. (note 18), 63-86 (Stern is quoted in 80). For more examples, see Comfort, op. cit. (note 3), Ch. 3. 127 Olga Amsterdamska, 'Medical and Biological Constraints: Early Research on Variation in Biology', Social Studies of Science, 17 (1987), 657-87.
} 